\title{
The evolving story of Borrelia burgdorferi sensu lato transmission in Europe
}

\author{
Antje Steinbrink $^{1,2} \cdot$ Katharina Brugger $^{3} \cdot$ Gabriele Margos $^{4} \cdot$ Peter Kraiczy $^{5} \cdot$ Sven Klimpel ${ }^{2,6,7}$ (1)
}

Received: 8 July 2021 / Accepted: 19 January 2022 / Published online: 5 February 2022

(c) The Author(s) 2022

\begin{abstract}
Beside mosquitoes, ticks are well-known vectors of different human pathogens. In the Northern Hemisphere, Lyme borreliosis (Eurasia, LB) or Lyme disease (North America, LD) is the most commonly occurring vector-borne infectious disease caused by bacteria of the genus Borrelia which are transmitted by hard ticks of the genus Ixodes. The reported incidence of LB in Europe is about 22.6 cases per 100,000 inhabitants annually with a broad range depending on the geographical area analyzed. However, the epidemiological data are largely incomplete, because LB is not notifiable in all European countries. Furthermore, not only differ reporting procedures between countries, there is also variation in case definitions and diagnostic procedures. Lyme borreliosis is caused by several species of the Borrelia (B.) burgdorferi sensu lato (s.l.) complex which are maintained in complex networks including ixodid ticks and different reservoir hosts. Vector and host influence each other and are affected by multiple factors including climate that have a major impact on their habitats and ecology. To classify factors that influence the risk of transmission of B. burgdorferi s.l. to their different vertebrate hosts as well as to humans, we briefly summarize the current knowledge about the pathogens including their astonishing ability to overcome various host immune responses, regarding the main vector in Europe Ixodes ricinus, and the disease caused by borreliae. The research shows, that a higher standardization of case definition, diagnostic procedures, and standardized, long-term surveillance systems across Europe is necessary to improve clinical and epidemiological data.
\end{abstract}

Keywords Borrelia $\cdot$ Ixodes $\cdot$ Lyme borreliosis $\cdot$ Lyme disease $\cdot$ Tick $\cdot$ Tick-borne diseases $\cdot$ Spirochetes

\section{Introduction}

Handling Editor: Julia Walochnik

Peter Kraiczy and Sven Klimpel share senior authorship.

Antje Steinbrink, Katharina Brugger and Gabriele Margos are contributed equally

Antje Steinbrink

antje.steinbrink@agrar.uni-giessen.de

1 Institute for Insect Biotechnology, Justus-Liebig-University of Giessen, Heinrich-Buff-Ring 26, 35392 Giessen, Germany

2 LOEWE Centre for Translational Biodiversity Genomics (LOEWE-TBG), Senckenberganlage 25, 60325 Frankfurt am Main, Germany

3 Unit for Veterinary Public Health and Epidemiology, University of Veterinary Medicine Vienna, Veterinärplatz 1, 1210 Vienna, Austria

4 German National Reference Centre for Borrelia, Bavarian Health and Food Safety Authority Branch, Veterinärstraße 2, 85764 Oberschleißheim, Germany
Vector-borne diseases (VBD) are a major global public health threat that affect more than one billion people and account for more than 700.000 deaths annually (WHO 2020). Most of the VBD are reported by low-income countries in

5 Institute of Medical Microbiology and Infection Control, University Hospital of Frankfurt, Goethe University Frankfurt, Paul-Ehrlich-Straße 40, 60596 Frankfurt am Main, Germany

6 Institute of Ecology, Evolution and Diversity, Goethe University Frankfurt, Max-von-Laue-Straße 13, 60438 Frankfurt am Main, Germany

7 Senckenberg Biodiversity and Climate Research Centre, Senckenberg Gesellschaft für Naturforschung, Senckenberganlage 14, 30325 Frankfurt am Main, Germany 
tropical and subtropical regions, but also countries of the Northern Hemisphere are faced with ongoing infections caused by vector-borne pathogens (WHO 2020). The most commonly occurring VBD of the Northern Hemisphere is Lyme borreliosis (LB) in Eurasia or Lyme disease (LD) in North America. Several species of the so-called Borrelia (B.) burgdorferi sensu lato (s.1.) complex are the causative agents of $\mathrm{LB}$, all of which are transmitted by hard ticks of the genus Ixodes (ECDC 2014; CDC 2021). In Europe, the reported incidence of LB cases per 100,000 inhabitants ranged from 0.6 in Ireland, to 80 in Sweden, and to 300 in Austria (Lindgren and Jaenson 2006). There are approximately 85,000 cases of LB notified in Europe each year (Sykes and Makiello 2017). In Germany, 60,000-200,000 cases have been estimated annually but the "true" number of LB cases lies likely somewhere in between (Müller et al. 2012; Hofmann et al. 2017; Rauer et al. 2020). Apparently, there is considerable epidemiological uncertainty regarding LB incidence and prevalence in Europe (Lindgren and Jaenson 2006; Hofmann et al. 2017; Rauer et al. 2020). Not only varies the annual incidence of reported LB cases greatly across European countries, there are also differences in the implemented surveillance systems in individual countries. This might account for the variation in the incidences as some take into consideration clinically well-diagnosed cases, while others also report probable or suspected LB cases. Furthermore, inconsistent case definitions, lacking of an implemented quality management system and nonuniform diagnostic procedures contribute to inaccurate epidemiological data (Lindgren and Jaenson 2006; Müller et al. 2012; Wilking and Stark 2014; Enkelmann et al. 2018).

Thus, observed increases in incidence or annual cases might be due to different data sources, changes in reporting procedures, expansion of ticks into regions previously cleared of ticks, or into newly created habitats, e.g., by renaturation and development of new environments, dispersal of natural hosts into low incidence regions, or due to increased awareness of general practitioners and the lay public (Kugeler et al. 2021). As Borrelia are strictly dependent on their vectors and reservoir hosts, it is important to understand the biotic and abiotic factors that determine the ecological dynamics in tick and Borrelia spreading to discern and manage the risk of humans to acquire the agent and develop LB. There is clearly a need to study these complex ecological networks over long periods of time, especially in the light of climate change, as tick life cycles can take several years to be accomplished and reservoir hosts like birds, squirrels, or hedgehogs are long-lived vertebrates (Hartemink et al. 2015; Stone et al. 2017). In this review, we give a brief overview about the driving factors making $B$. burgdorferi s.l. a human pathogen in Europe and where we stand and what should be done in the future for a better understanding of the close relationships between the pathogen, vector, hosts, and humans. Such knowledge can be used to enhance public information, to sensitize decision-makers and to improve diagnostic standards to prevent late manifestations.

\section{The B. burgdorferi s.I. species complex}

Spirochetes which comprise the $B$. burgdorferi s.l. complex were first discovered in ixodid ticks in the early 1980s (Burgdorfer et al. 1982) although it had been suspected since the beginning of the last century that tick-borne pathogens may cause symptoms that are now known as LB (reviewed by Stanek et al. 2002). The bacterium was named B. burgdorferi (Johnson et al. 1984), and it was believed to be a single bacterial species. The diversity of the species complex became apparent during subsequent investigations that unraveled the genetic and ecological heterogeneity of borreliae in Europe, Asia, and North America. Several new genospecies were identified in Europe but also in North America and Asia (Table 1) (Anderson et al. 1989; Baranton et al. 1992; Kawabata et al. 1993; Postic et al. 1993; Canica et al. 1993; Fukunaga et al. 1996; Le Fleche et al. 1997; Richter et al. 2006; Postic et al. 2007; Rudenko et al. 2009, 2011; Margos et al. 2013; Ivanova et al. 2014; Margos et al. 2014, 2015, 2016, 2017, 2020; Pritt et al. 2016). Since then, the name B. burgdorferi s.l. has been used to refer to the species complex, while $B$. burgdorferi s.s. refers to the species first discovered by Willy Burgdorfer and collaborators in the USA (Burgdorfer et al. 1982; Johnson et al. 1984). Currently, the B. burgdorferi s.l. species complex contains more than 20 validated and proposed genospecies (Table 1) of which six are assured human pathogens. The species are non-uniformly distributed mainly in the Northern Hemisphere between the latitudes of 40 and $60^{\circ} \mathrm{N}$. This distribution also reflects the presence of ixodid ticks (see Figures 1 and 2) and reservoir hosts. The ecological systems supporting natural transmission cycles of Borrelia are highly complex, and competent reservoir hosts and vectors may occur in sympatry with hosts or ticks with reduced or no reservoir/vector competence. The latter will negatively affect the success of Borrelia species or individual strains (Tsao 2009; Margos et al. 2019). Furthermore, not all vertebrates that are infected with a Borrelia species do indeed serve as a reservoir host. For many animal species, experimental evidence on reservoir competence has not been established so far (Wolcott et al. 2021). A rough indication of animal taxa that may serve as reservoirs for the different Borrelia species although not all species within these taxa may be competent reservoir hosts is summarized in Table 1. Seemingly, many Borrelia species have narrow host preferences, and very few species 
Table 1 Members of the Borrelia burgdorferi s.l. complex with their year of definition and valid publication, reference of description and their geographical distribution, suspected reservoir hosts, suspected vector species, and influence on human health. Species distributed in Europe are indicated in bold. The species B. finlandensis proposed by Casjens et al. (2011) is not included in this table because the Borrelia

\begin{tabular}{|c|c|c|c|c|c|c|c|}
\hline Borrelia species & Type strain & $\begin{array}{l}\text { Year of defini- } \\
\text { tion }\end{array}$ & $\begin{array}{l}\text { Year of valid } \\
\text { publication }\end{array}$ & $\begin{array}{l}\text { Suspected reser- } \\
\text { voir hosts }\end{array}$ & $\begin{array}{l}\text { Suspected vector } \\
\text { Ixodes spp. }\end{array}$ & Distribution & $\begin{array}{l}\text { Human } \\
\text { pathogenicity }\end{array}$ \\
\hline B. afzelii & VS461 & $\begin{array}{c}1993 \text { (Canica } \\
\text { et al. 1993) }\end{array}$ & $\begin{array}{l}1994 \text { (Validation } \\
\text { list no. 48. Int } \\
\text { J Syst Bac- } \\
\text { teriol 1994; } \\
\text { 44:182-183) }\end{array}$ & $\begin{array}{l}\text { Rodents, insecti- } \\
\text { vores }\end{array}$ & $\begin{array}{l}\text { I. ricinus, } I . \\
\text { persulcatus, I. } \\
\text { hexagonus }\end{array}$ & Asia, Europe & Yes \\
\hline B. americana & SCW-41 & $\begin{array}{l}2007 \text { (Postic } \\
\text { et al. 2007) }\end{array}$ & $\begin{array}{l}2009 \text { (Rudenko } \\
\text { et al. 2009) }\end{array}$ & Birds, rodents & $\begin{array}{l}\text { I. minor, I. } \\
\text { pacificus }\end{array}$ & North America & Unknown \\
\hline $\begin{array}{l}\text { Candidatus } B . \\
\text { andersonii }\end{array}$ & 21038 & $\begin{array}{l}1995 \text { (Marconi } \\
\text { et al. 1995) }\end{array}$ & & Birds, rabbits & I. dentatus & North America & Unknown \\
\hline $\begin{array}{l}\text { Candidatus } B . \\
\text { aligera }\end{array}$ & & $\begin{array}{l}2020 \text { (Norte } \\
\text { et al.2020b) }\end{array}$ & & Unknown & Unknown & Unknown & Unknown \\
\hline B. bavariensis & PBi & $\begin{array}{l}2009 \text { (Margos } \\
\text { et al. 2009) }\end{array}$ & $\begin{array}{l}2013 \text { (Margos } \\
\text { et al. 2013) }\end{array}$ & Rodents & $\begin{array}{l}\text { I. ricinus, } I \text {. } \\
\text { persulcatus }\end{array}$ & Asia, Europe & Yes \\
\hline B. bissettiae & DN-127 & $\begin{array}{l}1998 \text { (Postic } \\
\text { et al. 1998) }\end{array}$ & $\begin{array}{l}2016 \text { (Margos } \\
\text { et al. 2016) }\end{array}$ & Rodents & $\begin{array}{l}\text { I. spinipalpis, } I \text {. } \\
\text { pacificus }\end{array}$ & $\begin{array}{l}\text { Europe, North } \\
\text { America }\end{array}$ & Potentially \\
\hline $\begin{array}{l}\text { B. burgdorferi } \\
\text { s. s. }\end{array}$ & B31 & $\begin{array}{l}1984 \text { (Johnson } \\
\text { et al. 1984) }\end{array}$ & $\begin{array}{l}1984 \text { (Johnson } \\
\text { et al. 1984) }\end{array}$ & $\begin{array}{l}\text { Birds, rodents, } \\
\text { insectivores, } \\
\text { carnivores }\end{array}$ & $\begin{array}{l}\text { I. ricinus, } I \text {. } \\
\text { scapularis, } \\
\text { I. affinis, I. } \\
\text { pacificus, } \\
\text { I. minor, I. } \\
\text { hexagonus }\end{array}$ & $\begin{array}{l}\text { Europe, North } \\
\text { America }\end{array}$ & Yes \\
\hline B. californiensis & CA446 & $\begin{array}{l}2007 \text { (Postic } \\
\text { et al. 2007) }\end{array}$ & $\begin{array}{l}2016 \text { (Margos } \\
\text { et al. 2016) }\end{array}$ & Rodents & $\begin{array}{l}\text { I. pacificus, } I \text {. } \\
\text { spinipalpis, I. } \\
\text { jellisoni }\end{array}$ & North America & Unknown \\
\hline B. carolinensis & SCW-22 & $\begin{array}{l}2011 \text { (Rudenko } \\
\text { et al. 2011) }\end{array}$ & $\begin{array}{l}2011 \text { (Rudenko } \\
\text { et al. 2011) }\end{array}$ & Rodents & I. minor & North America & Unknown \\
\hline B. chilensis (p) & VA1 (p) & $\begin{array}{l}2014 \text { (Ivanova } \\
\text { et al. 2014) }\end{array}$ & & Rodents & I. stilesi & South America & Unknown \\
\hline B. garinii & 20047 & $\begin{array}{l}1992 \text { (Baranton } \\
\text { et al. 1992) }\end{array}$ & $\begin{array}{l}1992 \text { (Baranton } \\
\text { et al. 1992) }\end{array}$ & Birds & $\begin{array}{l}\text { I. ricinus, } I . \\
\text { persulcatus, } I \text {. } \\
\text { uriae }\end{array}$ & Asia, Europe & Yes \\
\hline B. japonica & HO14 & $\begin{array}{l}1993 \text { (Kawabata } \\
\text { et al. 1993) }\end{array}$ & $\begin{array}{l}1994 \text { (Validation } \\
\text { list no. 50. Int } \\
\text { J Syst Bac- } \\
\text { teriol 1994; } \\
\text { 44:595) }\end{array}$ & Rodents & I. ovatus & Asia & Unknown \\
\hline B. kurtenbachii & 25015 & $\begin{array}{l}2010 \text { (Margos } \\
\text { et al. 2010) }\end{array}$ & $\begin{array}{l}2014 \text { (Margos } \\
\text { et al. 2014) }\end{array}$ & Rodents & Unknown & North America & Potentially \\
\hline B. lanei & CA28-91 & $\begin{array}{l}2007 \text { (Postic } \\
\text { et al. 2007) }\end{array}$ & $\begin{array}{l}2017 \text { (Margos } \\
\text { et al. 2017) }\end{array}$ & Lagomorphs? & $\begin{array}{l}\text { I. spinipalpis, } I \text {. } \\
\text { pacificus }\end{array}$ & North America & Unknown \\
\hline B. lusitaniae & PoTiB2 & $\begin{array}{l}1997 \text { (La Fleche } \\
\text { et al. 1997) }\end{array}$ & $\begin{array}{l}1997 \text { (La Fleche } \\
\text { et al. 1997) }\end{array}$ & Lizards & I. ricinus & Europe & Potentially \\
\hline B. maritima & CA690 & $\begin{array}{l}2020 \text { (Margos } \\
\text { et al. 2020) }\end{array}$ & $\begin{array}{l}2020 \text { (Margos } \\
\text { et al. 2020) }\end{array}$ & Unknown & Unknown & North America & Unknown \\
\hline B. mayonii & M14-1420 & $\begin{array}{l}2016 \text { (Pritt et al. } \\
\text { 2016) }\end{array}$ & $\begin{array}{l}2016 \text { (Pritt et al. } \\
\text { 2016) }\end{array}$ & Rodents? & I. scapularis & North America & Yes \\
\hline B. sinica & CMN3 & $\begin{array}{l}2001 \text { (Masuzawa } \\
\text { et al. 2001) }\end{array}$ & $\begin{array}{l}2001 \text { (Masuzawa } \\
\text { et al. 2001) }\end{array}$ & Rodents & I. ovatus & Asia & Unknown \\
\hline B. spielmanii & PC-Eq17 & $\begin{array}{l}2004 \text { (Richter } \\
\text { et al. 2004) }\end{array}$ & $\begin{array}{l}2006 \text { (Richter } \\
\text { et al. 2006) }\end{array}$ & Rodents & $\begin{array}{l}\text { I. ricinus, } I \text {. } \\
\text { hexagonus }\end{array}$ & Europe & Yes \\
\hline
\end{tabular}

isolate (SV1) which was used to "define" the species B. finlandensis clusters in MLST phylogenies in the same clade as isolates NE49 and Z41293, and these were used to define species borders, i.e., they are enclosed in B. burgdorferi s.s. (see Postic et al. 2007, Margos et al. 2009). 
Table 1 (continued)

\begin{tabular}{|c|c|c|c|c|c|c|c|}
\hline Borrelia species & Type strain & $\begin{array}{l}\text { Year of defini- } \\
\text { tion }\end{array}$ & $\begin{array}{l}\text { Year of valid } \\
\text { publication }\end{array}$ & $\begin{array}{l}\text { Suspected reser- } \\
\text { voir hosts }\end{array}$ & $\begin{array}{l}\text { Suspected vector } \\
\text { Ixodes spp. }\end{array}$ & Distribution & $\begin{array}{l}\text { Human } \\
\text { pathogenicity }\end{array}$ \\
\hline B. tanukii & Hk501 & $\begin{array}{l}1996 \text { (Fukunaga } \\
\text { et al. 1996) }\end{array}$ & $\begin{array}{l}1996 \text { (Fukunaga } \\
\text { et al. 1996) }\end{array}$ & Rodents & I. tanuki & Asia & Unknown \\
\hline B. turdi & Ya501 & $\begin{array}{l}1996 \text { (Fukunaga } \\
\text { et al. 1996) }\end{array}$ & $\begin{array}{l}1996 \text { (Fukunaga } \\
\text { et al. 1996) }\end{array}$ & Birds & $\begin{array}{l}\text { I. turdus, } I \text {. } \\
\text { frontalis, } I \text {. } \\
\text { ricinus }\end{array}$ & Asia, Europe & Unknown \\
\hline B. valaisiana & VS116 & $\begin{array}{l}1997 \text { (Wang } \\
\text { et al. 1997) }\end{array}$ & $\begin{array}{l}1997 \text { (Wang } \\
\text { et al. 1997) }\end{array}$ & Birds & I. ricinus & Europe & No \\
\hline B. yangtzensis & Okinawa CW62 & $\begin{array}{l}2008 \text { (Chu et al. } \\
\text { 2008) }\end{array}$ & $\begin{array}{l}2015 \text { (Margos } \\
\text { et al. 2015) }\end{array}$ & Rodents & I. granulatus & Asia & Potentially \\
\hline
\end{tabular}

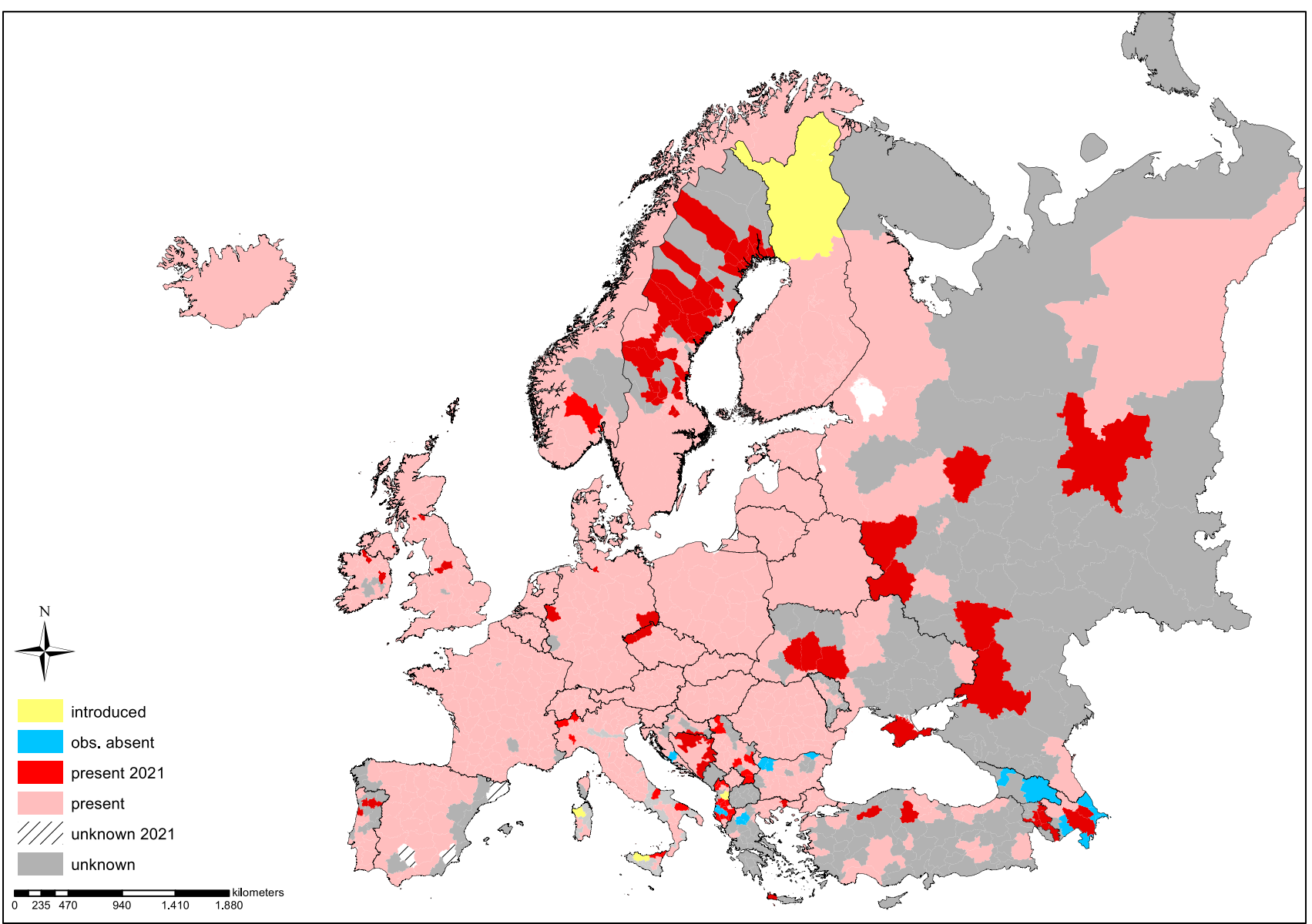

Figure 1 Distribution and changes in the prevalence of Ixodes rici$n u s$, the main vector of the Borrelia burgdorferi s.l. complex among Europe. The map is a compilation of reported findings of I. ricinus in 2017 (rosé and light blue) in comparison to 2021 (others color codes) reported to the ECDC (European Centre for disease Prevention and Control). Please note that the map depicts historical and actual findings condensed on NUTS-3 level, the European socio-economic,

can use divergent taxa as reservoir hosts. An example for a "generalist" species is B. burgdorferi s.s. as it can use or regional administrative level. However, no distinction is made between individual findings or stable populations. In addition, areas with "no data" should not interpreted as whether the species does or does not exist. Original maps can be accessed online: https://www. ecdc.europa.eu/en/disease-vectors/surveillance-and-disease-data/ mosquito-maps. Map was created with ArcGIS 10.8.

diverse mammalian and avian hosts as reservoir (Hanincová et al. 2006). 


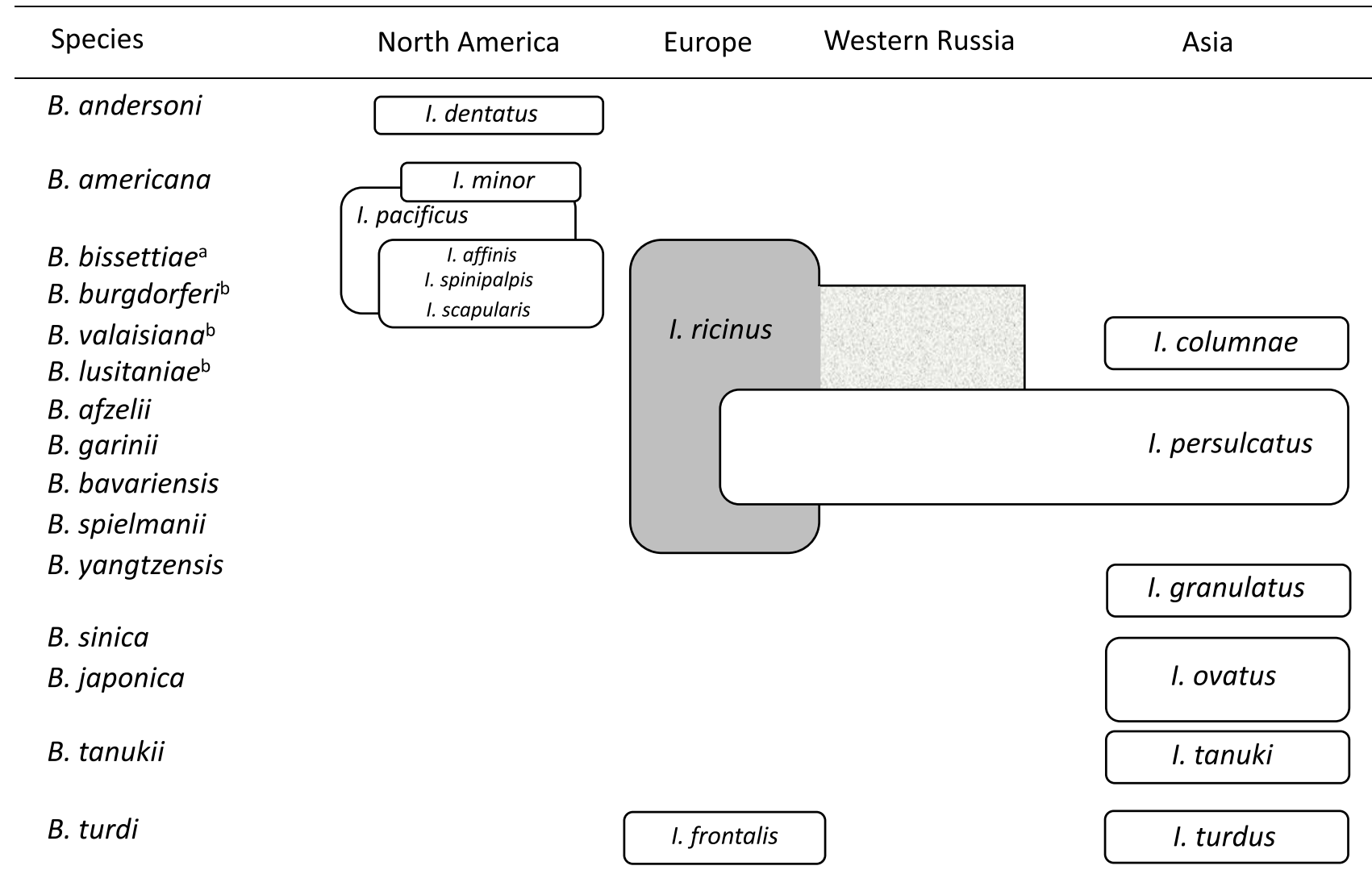

Figure 2 Geographic distribution and vector associations of Borrelia burgdorferi s.l. adapted after Margos et al. (2012) with new included Ixodes frontalis as vector for B. turdi in Europe. Abbreviations: I.,

\section{Ixodes ricinus: the European vector for $B$. burgdorferi s.l.}

More than 700 hard ticks (Acari: Ixodida: Ixodidae) are described worldwide, around $38 \%$ of which are feeding on humans but only 3\% regularly (Guglielmone et al. 2014; Cutler et al. 2021). Almost $13.2 \%$ of the 700 tick species are native in the Palearctic region. They are highly efficient vectors for pathogens of humans, livestock, companion animals, and wildlife (Estrada-Peña et al. 2017). In Europe, the most common endemic tick species is Ixodes ricinus, which is also known as castor bean tick or-on the British Isles-sheep tick (Estrada-Peña et al. 2013; Rubel et al. 2021). It is probably the best-studied species regarding its biology, ecology, and role as a vector for certain pathogens (Gray et al. 2016). In the northeast, its distribution overlaps with another B. burgdorferi s.l. vector, I. persulcatus (Swanson et al. 2006). Ixodes ricinus prefers habitats that offer optimal microclimatic conditions and a host composition suitable for blood meals of all three life stages. Especially, a permanent, deep leaf litter provides microclimatic temperature and humidity conditions for all developmental tick stages that enable them to survive for the
Ixodes; B. Borrelia; ${ }^{\text {afor }}$ B. bisettiae, the vector for Europe is uncertain; ${ }^{\mathrm{b}}$ B. burgdorferi, B. valaisiana, and B. lusitaniae are transmitted by I. ricinus in Eastern Europe but their prevalence is low.

time between blood meals, even in temporarily dry periods (Kahl 2018). Hence, high tick densities are typically found in deciduous or mixed forest but also in coniferous forest, urban parks, cemeteries, or even gardens close to woods (Gray et al. 1998; Boehnke et al. 2015; Brugger et al. 2016). Also, I. hexagonus and I. persulcatus are proven vectors for B. burgdorferi s.l. (Eisen 2020). Although B. burgdorferi s.l. has frequently been detected in other hard-bodied tick species, e.g., Dermacentor reticulatus and Haemaphysalis concinna, it was experimentally confirmed that they are not vector competent for Borrelia (Eisen and Lane 2002; Eisen 2020).

\section{The interrelationship between B. burgdorferi s.l., ticks, and their vertebrate hosts}

The transmission cycle of $B$. burgdorferi s.l. is closely related to the life cycle of their vectors, ticks of the genus Ixodes (Figure 3). In Europe, the life cycle of I. ricinus comprises four developmental stages: egg, larva, nymph, and adult (female/male). Each of the three post-embryonic life stages (larvae, nymphs, adult females) must take a 


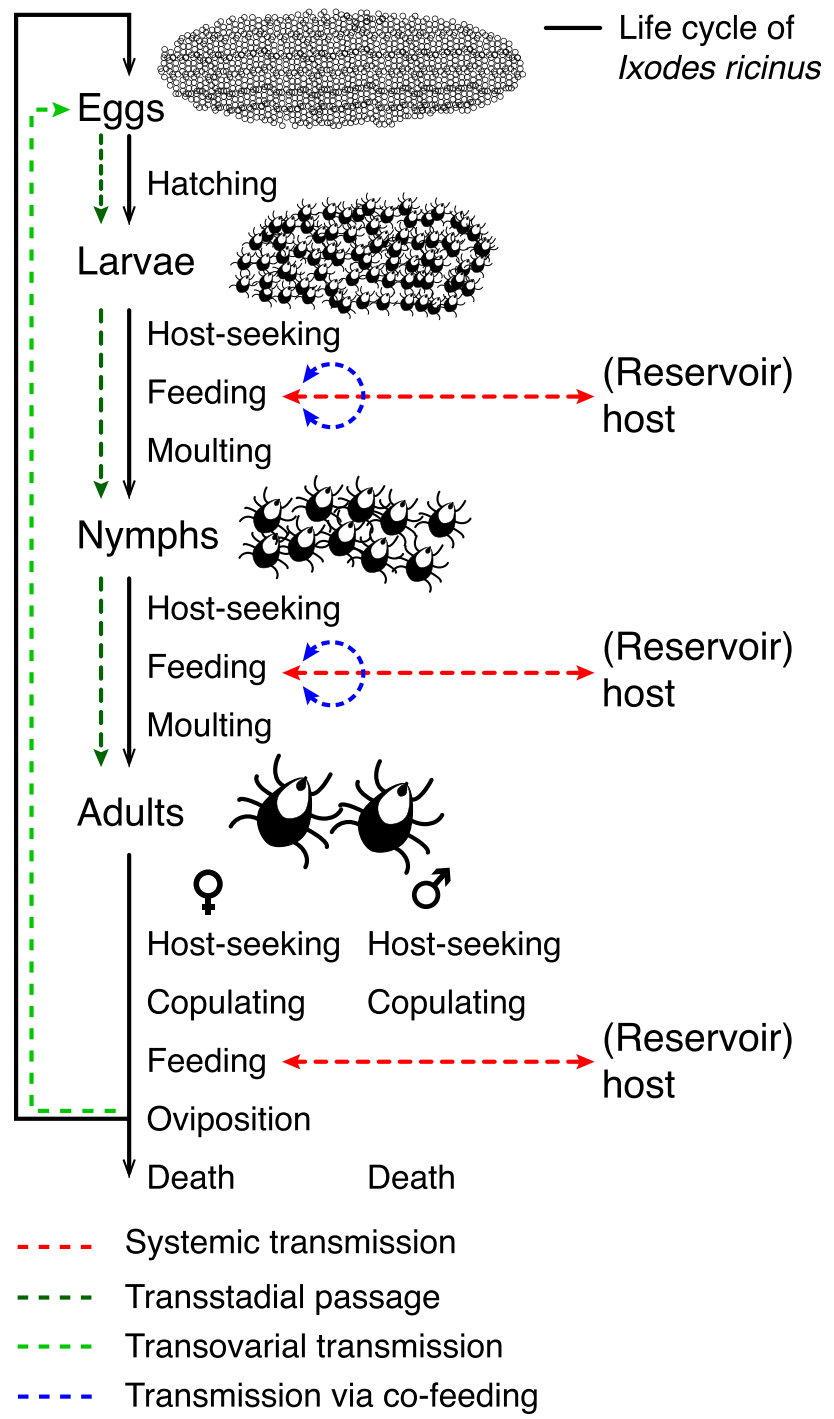

Figure 3 The life cycle of Ixodes ricinus. In general, the number of ticks in each stage is about one order of magnitude smaller than in the preceding stage (Randolph 1998). Approximately 200 larvae hatch from 2000 eggs, which molt after successful blood meals into 20 nymphs and then after further blood meals into 2 adults (female and male). Additionally, the Borrelia burgdorferi s.l. cycle between $I$. ricinus as the main vector and (reservoir) hosts are given.

blood meal to reach the next stage or-in the case of female adults-to produce and deposit eggs (Figure 3). Generally, I. ricinus complete their life cycle within 3 years, but it can take up 6 years depending on environmental conditions such as weather, length of cold periods, temperature, and others all of which induce quiescence, developmental diapauses, or behavioral diapauses (Gray et al. 2016). Depending on the geographical regions and microclimatic conditions, larvae are active roughly from end of April to end of October. In northern and central Europe, nymphs and adults are active from March to November with a peak in April or May and a decrease during warm and dry periods (e.g., in summer months). During very mild weather periods in winter, nymphs and adults can also become active. Late winter onsets in spring cause temporary decreases in activity (Gray et al. 2016). Knowing the biotic and abiotic variables that influence tick density enables forecasting the next year's tick density. In the case of nymphal I. ricinus, the variables are the mean annual temperature of the previous year, the current mean winter temperature, and the fructification of the European beech 2 years before (Brugger et al. 2018; Bregnard et al. 2020, 2021). The latter is representative for the different types of tree seeds that small rodents feed on. Although I. ricinus feeds on a broad range of vertebrate species, including rodents, birds, insectivores, reptiles, and deer, only a few species are known to act as a reservoir host for B. burgdorferi s.l., i.e., host species that participate significantly in the natural circulation of the bacteria (Gern et al. 1994, 1997, 1998; Kahl et al. 2002; Estrada-Peña et al. 2017; Wolcott et al. 2021). Principal reservoir hosts are rodents, such as Apodemus sylvaticus, A. flavicollis, and Myodes glareolus (previously Clethrionomys glareolus); insectivores, such as Sorex minutus and Erinaceus europaeus; hares such as Lepus europaeus; lizards such as Psammodromus algirus and Lacerta agilis; or bird species such as Turdus sp. or Parus major (Gern et al. 1998; Kurtenbach et al. 1998, 2002b; Dsouli et al. 2006; Lindgren and Jaenson 2006; Ekner et al. 2011; Norte et al. 2013; Heylen et al. 2014a, b, 2017; Norte et al. 2020a).

During attachment and feeding of a vector tick on a (reservoir) host, spirochetes can be transmitted from an infected tick to a host or vice versa known as systemic transmission which is the main route how ticks acquire borreliae from an infected host (Figure 3, Kurtenbach et al. 2002b; Mannelli et al. 2011). The passage of spirochetes acquired during feeding of one tick life stage through molting to the next stage(s), i.e., from larva to nymph to adult, is called transstadial passage (Gern and Humair 2002). In very rare cases, $B$. burgdorferi s.l. is also transmitted from the adult female to the next generation called transovarial transmission, but this scenario may depend on the tick and Borrelia species involved (Gern and Humair 2002; Lindgren and Jaenson 2006; van Duijvendijk et al. 2016). In addition, the so-called co-feeding transmission, i.e., feeding of infected and uninfected ticks in spatiotemporal proximity to each other on the same reservoir, has extensively discussed previously (reviewed by Voordouw 2015).

As with most tick-borne pathogens, B. burgdorferi s.l. is acquired during the larval or nymphal stage and is transmitted to new hosts mainly by nymphs or adults (Kurokawa et al 2020). Adults usually feed on non-reservoir competent hosts like deer (Jaenson and Tälleklint 1992; Mysterud et al. 2014). Nymphs are considered the main vector for B. burgdorferi s.l. to humans, as the number of nymphs is an order of magnitude greater than the number of adults, 
they are smaller, and thus more difficult to detect than adults (Randolph and Craine 1995; Hubálek 2009; Diuk-Wasser et al. 2012). Animal models indicate that B. burgdorferi s.l. transmission may occur as early as $16 \mathrm{~h}$ and frequently as early as $24 \mathrm{~h}$, but this process depends on the involved host, tick, and Borrelia species or even individual Borrelia strains (Kahl et al. 1998; des Vignes et al. 2001). Nevertheless, the minimum attachment for a successful Borrelia transmission to humans has never been determined. Several studies dealing with the transmission of Borrelia to humans suggest a low risk of developing LB even after a bite of an infected tick (Fryland et al. 2011; Huegli et al. 2011; Wilhelmsson et al. 2016; Markowicz et al. 2021). In these studies, approximately $5 \%$ of bitten individuals were infected with spirochetes (established by analyzing seroconversion) and participants who developed symptoms ranged between 2 and 3\%. In a study in the Rhine-Main area (Germany), antibodies against borreliae were detected in about $15 \%$ of blood-donor samples (Hunfeld et al. 1998).

Furthermore, the prevalence of B. burgdorferi s.l. in host-seeking $I$. ricinus can vary greatly by region and by year. Two meta-analyses were conducted for the periods 1984-2003 and 2010-2016, respectively, that showed an increasing prevalence from west to east Europe (Rauter and Hartung 2005; Strnad et al. 2017). Interestingly, the overall mean prevalence did not increase during that time: it was $13.7 \%$ for the first period and $12.3 \%$ for the second period. While the prevalence in adults was higher $(18.6 \%)$ in the first period than in the second period (14.9\%), it is almost the same in nymphs (10.1\% vs. $11.8 \%)$. Similarly, longterm studies, analyzing data over time periods of 6 to 10 years, have shown that in the Netherlands, infection rates of questing I. ricinus remained stable when the whole period of time was considered. Only in 2 years $(2004,2005)$ during the investigation, higher prevalences were observed which, however, declined to "normal" values afterwards (Coipan et al. 2013). A long-term study conducted in Latvia collected ticks for a time period of 12 years (1999-2010) in the same habitats. The results were surprising because they showed an initially high prevalence of Ixodes infected with $B$. burgdorferi s.l. followed by a steady decline of prevalences from 2001 to 2010 (Okeyo et al. 2020). The reasons for such a decline are as yet unknown.

To conclude, ixodid ticks seem to be an optimal vector for the spread and survival of B. burgdorferi s.l. for the following reasons:

1. Duration of the feeding period for larvae up to 4 days, nymphs 5 days, and female adults 10 days (Kahl 1989) favors transmission of microorganisms in both directions (tick to host or host to tick) if the tick is vector-competent and the host reservoir-competent.
2. Bacterial uptake and transmission take place via four routes: systemic, transstadial, transovarial, and via cofeeding, but efficiency of transmission may be strain dependent (Tonetti et al. 2015).

3. The broad host range of Ixodes spp. (more than 300 vertebrate species including rodents, birds, insectivores, reptiles, see Gern and Humair 2002; Estrada-Peña et al. 2017) enables a transmission between different hosts. However, it needs to be considered that not all Borrelia species are able to use all vertebrate hosts as a reservoir, and thus, some hosts may negatively influence transmission of certain Borrelia species.

4. Hosts enable a spatial dispersal of ticks through passive transport during feeding: about 200-300 m per generation through rodents (Rudenko et al. 2014), about 50-100 hectares by deer (Lindgren and Jaenson 2006), and much larger distances through migratory passerine birds (Hasle et al. 2009; Vollmer et al. 2011, 2013).

5. High reproductive potential as female adults are capable of laying up to 2,000 eggs.

6. Ability to withstand or circumvent most environmental constraints through quiescence or diapause and/or longer periods of starvation prolongs the life cycle and therefore also the infected period.

\section{Strategies of B. burgdorferi s.l. to survive in ticks and vertebrate hosts}

Borrelia burgdorferi s.l. have developed sophisticated strategies to successfully perpetuate in their vector-hosttransmission cycle (e.g., Anguita et al. 2003; Kung et al. 2013; Coburn et al. 2020). They can persistently infect and survive in their reservoir hosts for prolonged periods of time without causing any signs of a disease in the infected animals. In fact, spirochetes developed numerous strategies to overcome the innate and the adaptive immune response to prevent elimination by the host's immune system (Hyde 2017; Kurokawa et al. 2020; Lin et al. 2020; Anderson and Brissette 2021). The 1780 genes in the genome of B. burgdorferi s.s. strain B31 M1 are located on a single linear chromosome (910 kbp) and 21 linear and circular plasmids (Fraser et al. 1997; Casjens et al. 2000; Pal and Fikrig 2003; Schwartz et al. 2021) and can be regulated to respond to environmental changes. Spirochetes are capable to alter the regulation of multiple genes involved in cell metabolism, motility, interaction with host- and tick-derived molecules, and thereby impacting responses of their vectors and hosts. The regulation of genes is primarily driven by three distinct systems: the RpoN-RpoS alternative sigma $(\sigma)$ factor cascade, the Hk1(histidine kinase 1)-Rrp1 (response regulatory protein) 
two-component system (TCS) including the secondary messenger c-di-GMP, and the DksA (DnaK suppressor) and $\mathrm{Rel}_{\mathrm{Bbu}}$ regulons (summarized in Samuels et al. 2021). Borrelia gene expression seems to be mainly affected by temperature, $\mathrm{pH}$, nutrients (organic and short-fatty acids), osmolarity, carbon dioxide, oxygen, metals, or cell density (Stevenson et al. 1995; Carrol et al. 1999; Revel et al. 2002; Anguita et al. 2003; Pal and Fikrig 2003, reviewed in Samuels et al. 2021). The most prominent examples for differential gene regulation are OspA and OspC known to play a major role in colonization of the tick midgut and transmission to the vertebrate host and establishment of an infection (Pal and Fikrig 2003; Pal et al. 2004; Radolf et al. 2012; Kung et al. 2013; Tilly et al. 2016).

\section{Evading host innate immunity}

Concerning the strategies used by $B$. burgdorferi s.l. to overcome innate immunity of different hosts, one molecular driver contributing to host speciation of B. burgdorferi s.l. appears to be strain-specific complement evasion of Borrelia by producing allelic variable complement-inactivating proteins (Kraiczy 2016a, b; Coburn et al. 2020; Skare and Garcia 2020; Lin et al 2020; Hart et al. 2021).

Common to all vertebrates and human, complement acts as a powerful surveillance system and, therefore, forms an important cornerstone of innate immunity to recognize, label (opsonize), and eliminate invading microorganisms. Upon recognition, complement activation finally leads to the generation of a cell-destroying, membrane attack complex (MAC) on the spirochetal surface. Noteworthy, species of the B. burgdorferi s.l. complex largely vary in their ability to survive in the presence of complement obtained from different vertebrates (Kurtenbach et al. 1998, 2002a; Kraiczy 2016a, b; Tufts et al. 2019; Lin et al. 2020; Sürth et al. 2021). Apparently, the ability of a Borrelia species to resist complement-mediated killing by a particular host's serum almost always correlated with the capability of this specific Borrelia species to successfully infect and survive in that host and utilize it as reservoir (Kurtenbach et al. 2002a; Lin et al. 2020). While Borrelia species such as $B$. afzelii, B. spielmanii, B. bavariensis, B. bissettiae, $B$. mayonii, and $B$. japonica generally survive in mammalian but not in avian sera, $B$. garinii and $B$. valaisiana known to be associated with birds, resist killing by avian complement (Kurtenbach et al. 1998, 2002a; Kraiczy 2016a; Lin et al. 2020). In addition, B. burgdorferi s.s. frequently isolated from mammalian hosts and birds survived in these sera indicating that this Borrelia species is more likely to be considered a "generalist" (Lin et al. 2020). In fact, the characteristic serum resistance pattern(s) raises the possibility that complement contributes to Borrelia transmissibility, host adaptation, and overall dispersal of spirochetes in nature and, thus, plays an important role in Borrelia ecology.

\section{Complement-interacting proteins of Lyme borreliae}

Borrelia are well-equipped with polymorphic immune evasion molecules affecting complement at different activation levels and that are produced at distinct times points during the tick-mammalian infection cycle to achieve an utmost protection against the harmful attack of hosts innate immunity (Bykowski et al. 2007; Kraiczy 2016b; Hart et al. 2018; Marcinkiewicz et al. 2019; Coburn et al. 2020; Lin et al. 2020; Hart et al. 2021). These allelically distinct and genetically unrelated molecules display specific complement-inhibitory activities. Due to the mode of inactivation, they are classified as proteins that indirectly inhibit complement by capturing host-derived complement regulators (C4BP, factor $\mathrm{H}(\mathrm{FH})$, factor $\mathrm{H}$-like protein-1 (FHL-1), factor H-related proteins (FHR)) from the fluid phase or as proteins that directly bind to distinct complement components $(\mathrm{C} 1 \mathrm{r}, \mathrm{C} 4 \mathrm{~b}, \mathrm{C} 7, \mathrm{C} 8$, and $\mathrm{C} 9$ or the formed membrane attack complex (MAC)) and thereby specifically inhibit complement activation (Kraiczy 2016b; Lin et al. 2020; Skare and Garcia 2020). The first group consists of the C4BP-binding protein, $\mathrm{p} 43$, the FH/FHL-1-binding proteins CspA and CspZ, and the FH/FHR-binding OspE/F-related (Erp) proteins ErpA, ErpC, and ErpP (Kraiczy et al. 2001; Pietikainen et al. 2010; Kraiczy 2016b; Hellwage et al. 2001). The FH/FHL-1/FHR-binding proteins are collectively referred to as "complement regulator-acquiring surface proteins or CRASP" (Kraiczy et al. 2001). Functional analyses revealed that recruitment of complement regulators C4BP and FH/FHL-1 result in an efficient inactivation of either $\mathrm{C} 4 \mathrm{~b}$ or $\mathrm{C} 3 \mathrm{~b}$ and consequently in the inhibition of all activation pathways. The second group includes at least two proteins (BBK32 and OspC) targeting the early activation steps of the classical (CP) and lectin pathway (LP) by interfering with $\mathrm{C} 1 \mathrm{r}$ or $\mathrm{C} 4 \mathrm{~b}$, and three molecules (CspA, BGA66, and BGA71) that inhibit MAC formation by binding to the late complement components $\mathrm{C} 7, \mathrm{C} 8$, and $\mathrm{C} 9$, respectively (Hallström et al. 2013; Hammerschmidt et al. 2014, 2016; Caine et al. 2017; Garcia et al. 2016).

Among complement-interacting proteins, BBK32, CspA, CspZ, BGA66, and BGA71 confer resistance to complement-mediated killing (Hallström et al. 2013; Hammerschmidt et al. 2014, 2016; Garcia et al. 2016). Moreover, recent observations support the notion of an adapted immune evasion strategy to affect complement at different time points of the tick-mammalian infection cycle. CspA protects spirochetes in the tick gut during the feeding process (Hart et al. 2018), while CspZ is produced when spirochetes enter and persist in the murine host (Marcinkiewicz et al. 2019). The 
expression profile of the $b b k 32$ gene suggests a complement protective role of BBK32 during the early stage of dissemination and at late time points when spirochetes infect tissues (Lin et al. 2015; Caine and Coburn 2015). In contrast, OspC appears to operate only at the initial phase of infection by either binding to the anti-complement tick Salp15 protein or by direct interaction with $\mathrm{C} 4 \mathrm{~b}$, thereby preventing spirochetes from opsonophagocytosis (Ramamoorthi et al. 2005; Caine et al. 2017). Whether the polymorphic OspE proteins shield spirochetes from complement-mediated killing in vivo still remains unclear. Previous findings indicate that OspE proteins can promote spirochete dissemination and transmission from tick to the vertebrate host (Lin et al. 2012). Furthermore, the strain- and species-specific polymorphism among OspE proteins and their ability to bind FH from diverse vertebrates (Stevenson et al. 2002; Mühleip et al. 2018) raises the possibility that these molecules most likely participate in immune evasion and host tropisms of Lyme borreliae. It should be considered that almost all data collected so far have been obtained from studies investigating $B$. burgdorferi s.s. and, therefore, additional yet unidentified proteins of other Borrelia species may also possess anti-complement activities.

\section{Evading host adaptive immunity by antigenic variation}

All Lyme borreliae species carry a $v l s$ ( $\underline{v} m p$-like sequence) locus consisting of a single expression site $(v l s E)$ and a variable number of silent cassettes to escape from the host's acquired immune response (Zhang et al. 1997; Norris 2014). By random segmental gene conversion ("switching") events, portions of the variable domain of the $v l s E$ expression site are replaced by homologous sequences of any of the silent cassettes to generate an antigen in which the variable region differs from the initial VlsE protein. Importantly, the switching events in B. burgdorferi calculated to be in theory $3.3 \times 10^{-2}$ per cell per generation (Norris 2014; Verhey et al. 2018; Chaconas et al. 2020) do not occur during in vitro culture or in infected ticks (Zhang and Norris 1998; Indest et al. 2001). In mice, variable sequences in the VlsE protein can be detected as early as 4 days post-infection, and after 28 days, every single Borrelia cell isolated from infected tissues carries sequence variations in the $v l s E$ genes as a result of individual recombination events (Zhang and Norris 1998). By altering the outer surface composition, in particular due to a continuous process of modifying highly immunogenic antigens like VlsE, the heterogeneous Borrelia population generated allows a subpopulation to be unrecognized by the host immune system and, thus, escape from the adaptive immune response. Moreover, the appearance of new VlsE variants shortly after transmission of spirochetes perfectly matches the timing when the first IgM antibodies are detectable in the host, in general at two weeks of initial infection, to eliminate the invading pathogen. In succession, the humoral immune response remains always a step behind, thus enabling Borrelia cells to persistently infect their reservoir hosts. Noteworthy, B. burgdorferi s.s. B31 lacking linear plasmid lp28-1 on which the vls locus is arranged at the right telomere are efficiently eliminated from immunocompetent mice within 3 weeks post-infection but could be cultivated without the pressure of an adaptive immune system from infected tissues of SCID mice deficient in T and B lymphocytes (Labandeira-Rey et al. 2003; Purser et al. 2003). These findings strongly indicate that antigenic variation is an essential requisite of Lyme borreliae to avoid immune surveillance and to maintain the natural life cycle.

\section{The disease: general aspects, case definitions, diagnosis, and treatment}

Lyme arthritis or later on LD was first reported in the late 1970 s by Steere et al. and is named after the town "Old Lyme," Connecticut, in the USA (Johnson et al. 1984; Steere et al. 1977, 2016), while in Eurasia, the term LB is used. Since 1991, LD is a nationwide notifiable disease in the USA with 25,000-30,000 confirmed cases reported to public health systems annually (Borchers et al. 2015; CDC 2019). In 1996 and 2008, an increase of case numbers in the USA were noticed, likely due to the improvement of diagnostics (1996) and the introduction of a clearer case definitions in 2008 (Schwartz et al. 2017). It remains to be seen whether the updated guidelines by Wormser et al. (2021) will also show effects. In a more recent analysis based on case numbers in health insurance data, Kugeler et al. (2021) estimated that during 2010-2018, approximately 476,000 persons were diagnosed with LB annually (which also includes false-positive test results) in the USA. In Germany, available data suggest an incidence of LB between 60,000 and 200,000 cases annually (Müller et al. 2012; Rauer et al. 2020). Of note, incidences based on health insurance data also include false diagnoses due to the consultation of several health practitioners by the same patient or misassignment of the DRG Code, etc. (Müller et al. 2012; Kugeler et al. 2021). Thus, the lower numbers may result from underreporting while the higher numbers are overestimations and the true number of LB cases lies very likely somewhere in between (Müller et al. 2012; Hofmann et al. 2017; Rauer et al. 2020). But why is it so difficult to get accurate numbers for LB cases? The answer lies on one hand in the complexity of the system: it is demanding to get accurate data and numbers on tick densities, infection prevalences of ticks with Borrelia, tick bites, and other signs of infection that may go unnoticed. :On the other hand, inaccuracies with the reporting systems in spite of clear clinical case definitions and the uncertainties 
in diagnostic methods make it difficult to obtain accurate numbers of human LB cases (Kugeler and Eisen 2020). The gold standard of microbiological diagnostics is the cultivation of the causative agents. Borreliae are fastidious bacteria that need a very rich culture medium for their growth. These bacteria also grow very slowly under in vitro conditions (generation time 8-12 h) (Barbour 1984; Preac-Mursic et al. 1986; Wang et al. 2004). The number of spirochetes in human biopsies or specimens is often extremely low making adaptation of the bacteria to culture conditions very difficult because adaptation to an artificial medium is a strong selection process (Norris et al. 1997; Stupica et al. 2011). Clinical and laboratory data (often based on the detection of antiBorrelia antibodies and borrelial DNA by PCR) as well as the history of a tick bite need to be taken into consideration. Moreover, the interpretation of test results requires ample diagnostic experience as well (Steere et al. 2016; Stanek et al. 2011). As already mentioned above, guidelines for diagnosis of LB (Mygland et al. 2010; Stanek et al. 2011; Hofmann et al. 2017; Gocko et al. 2019; Rauer et al. 2020) and the reporting of LB cases are highly inconsistent in European countries, especially due to different case definitions and country-specific reporting systems (Smith and Takkinen 2006; Schotthoefer and Frost 2015; Stone et al. 2017; Sykes and Makiello 2017).

In general, LB is characterized as a multisystemic disorder whose symptoms can be confused with other infections and which can be separated into early and late manifestations. Early manifestations may be localized or disseminated and may present as erythema migrans (EM), Borrelia lymphocytoma, Lyme neuroborreliosis, carditis, or ophthalmic borreliosis (Stanek et al. 2011; Hofmann et al. 2017; Rauer et al. 2020). Erythema migrans or bull's-eye rash in North America is the most common objective clinical manifestation of LB reported in about $70-90 \%$ of the cases (e.g., Rauer et al. 2020). It was first described about 110 years ago by the Swedish physician Arvid Afzelius (Afzelius 1921; Steere 2006) and is defined as an expanding, reddish skin lesion directly at the biting site which occurs 3-30 days after the bite of an infected tick (Huppertz et al. 1999; Stanek et al. 2011; Hofmann et al. 2017; Hyde 2017; Stone et al. 2017; Sykes and Makiello 2017; van den Wijngaard et al. 2017). Often, LB might be accompanied by other symptoms like fever, fatigue, headache, mild stiff neck, arthralgia, or myalgia (Stanek et al. 2011; Borchers et al. 2015). Although EM may often be self-limiting, in some cases other organs such as skin, central nervous system, and joints, can be affected due to dissemination of the pathogen (Stanek et al. 2011; Rauer et al. 2020). This may result in more severe symptoms such as mono- and oligoarthritis of large joints, meningoradiculoneuritis (Garin-Bujadoux-Bannwarth syndrome) often combined with facial palsy, or in very rare cases (4\% of patients with Lyme neuroborreliosis) myelitis with spastic atactic gait disturbance and bladder dysfunction as an affect of the disease to central nervous system (Stanek et al. 2011; Hyde 2017; Rauer et al. 2020). Based on studies from Sweden and Germany, EM was diagnosed in 77\% (Sweden) and 89\% (Germany) of LB cases, while Lyme neuroborreliosis was observed in $16 \%$ (Sweden) and 3\% (Germany). Lyme arthritis was diagnosed in 7\% (Sweden) and 5\% (Germany) of LB cases (Berglund et al. 1995; Huppertz et al. 1999). The clinical presentation of the disease is at least in part similar between Europe and North America. Due to the different Borrelia species, clinical manifestations like borrelial lymphocytoma (early disseminated manifestations), late neuroborreliosis, or acrodermatitis chronica atrophicans (both late manifestation) are mainly reported from Europe (Glatz et al. 2015; Steere et al. 2016). The diagnosis of LB is highly based on the presence of specific clinical symptoms, but confirmation by reliable laboratory diagnostics, except for EM, is strongly recommended (Lindgren and Jaenson 2006; Stanek et al. 2011; Leeflang et al. 2016; Hofmann et al. 2017; Petrulionienè et al. 2020; Rauer et al. 2020). As many LB patients do not recall a tick bite or an EM, serological testing of anti-Borrelia antibodies is the mainstay of laboratory diagnostic. Direct detection of spirochetes in different specimens often lack sufficient specificity or sensitivity, e.g., by culturing of spirochetes and PCR-based methods, although the latter have been improved in recent years. In cases of acute Lyme neuroborreliosis, the chemokine CXCL13 shows significantly elevated levels, and ELISA tests provided very promising results for diagnostic utility (Rupprecht et al. 2018). By reviewing 16 different guidelines from Europe and North America for the diagnosis of LB, Eldin et al. (2019) concluded that a two-tier serology should be the method of choice consisting of an initial sensitive screening test (generally ELISA) which-in the case of a positive test result — should be followed by a confirmatory test such as an immunoblot (Strle and Stanek 2009; Dessau et al. 2018; Lohr et al. 2018; Mead et al. 2019). According to the duration of clinical symptoms and manifestations, a guideline-based, 14-21-day course of antibiotic therapy is recommended to eradicate the pathogen (Hansmann 2009; Steere et al. 2016; Gocko et al. 2019; Rauer et al. 2020). Unfortunately, there is no vaccine against human LB on the market; therefore, personal protection as wearing long clothes, using tick repellents, and checking the body for ticks after outdoor activity is an important prophylaxis (Schotthoefer and Frost 2015; Petrulionienė et al. 2020; Lantos et al. 2021) 


\section{Epidemiological data: an ongoing challenge}

As already mentioned, there are considerable uncertainties in epidemiological data, especially regarding LB incidence and prevalence (Lindgren and Jaenson 2006; Hofmann et al. 2017; Rauer et al. 2020).

Reports based on seroprevalence did not find an increase in the overall incidence (Semenza and Menne 2009; Vanthomme et al. 2012; Medlock et al. 2013; Cuellar et al. 2019; Woudenberg et al. 2020). In fact, a retrospective study conducted in Finland on the Borrelia seroprevalence of the population from 1962 to 1972 revealed a seroprevalence of $20 \%$ which is much higher than that reported for 2011 (3.9\%) (Cuellar et al. 2019). Seemingly, the situation in Europe is similar to that in the USA, where from 2008 to 2015 annual cases of LD are almost stable in high incidence regions where Borreliainfected I. scapularis ticks have been endemic, while cases have increased in neighboring countries (Schwartz et al. 2017). Also, the annual number of reported human LB cases per 100,000 inhabitants varies greatly across Europe and within individual countries (from 0.6 in Ireland to 300 in Austria) (Lindgren and Jaenson 2006). Germany is a typical example of how challenging it is to get reliable and comparable data of LB cases. As discussed by Wilking and Stark (2014) and Enkelmann et al. (2018), there is no nationwide mandatory notification system for LB cases. Currently, physicians and/or laboratories in nine of the 16 German federal states are obliged to report LB cases to their local health authorities. As shown by Enkelmann et al. (2018), peaks in case numbers are clearly correlated to the changes in reporting. The same situation holds true for the USA (Schwartz et al. 2017).

To address the drawback of an inconsistent reporting procedure, the European Commission added Lyme neuroborreliosis to the list of diseases for epidemiological surveillance in 2018. All EU member states are obliged to submit their available national data to the European Centre for Disease Prevention and Control (ECDC) to establish a uniform case definition but also treatment and reporting system. However, the member states are not yet obliged to introduce a new mandatory notification (EU 2018/945, The Lancet 2018). Comparing LB incidences, tick density data, and Borrelia prevalence data across Europe would be an important step to better assess the risk of acquiring a Borrelia infection and developing LB. Implementation of appropriate measures such as adequate training and education of health professionals about the topic will advance diagnostic certainty. Also, specific tick control programs may help leveling out risk hot spots and thus would sensitize the population even more to this topic. In the case of tick-borne encephalitis (TBE), a viral human pathogen that is also transmitted by ticks, the nationwide notification has led to improve epidemiological data. Potential risk areas are validated and adapted from time to time, and specific recommendations such as vaccination (for TBE) by health professionals can be made. Standard definitions and reporting systems also produce more reliable data about the progression of infections over time, e.g., due to climate change or other factors (e.g., changes in the behavior of people going into the nature because of the coronavirus pandemic) (Hellenbrand et al. 2019; RKI 2021).

\section{Risk assessments for human exposure to $B$. burgdorferi s.l.}

Prevention and control of LB is an important aspect for public health considerations. Therefore, the factors that regulate and trigger the epidemiological triangle of the pathogen, vector, and hosts must be clearly identified and examined (Margos et al. 2011; Lou and Wu 2017). Such factors comprise climatic parameters (e.g., temperature, precipitation, relative humidity), environmental parameters (e.g., land cover, altitude, normalized difference vegetation index (NDVI)), and host or human-related parameters (e.g., density, immune response to the pathogen, regeneration, or urban greening). Risk assessments, which quantify the spatial and/or temporal risk for humans to acquire an infection caused by B. burgdorferi s.l., refer either to an acarological risk, i.e., the density and distribution of host-seeking Borrelia-infected ticks, or directly to human incidence (Killilea et al. 2008; Margos et al. 2011). Basically, there are two methodological approaches to understand the dynamics of the complex ecosystem and to quantify the risk for humans to get infected: statistical models, which aim to describe the relationship between risk (infected ticks or human incidence) and predictors, and mathematical models, which aim to simulate the vectorhost-pathogen-transmission cycle including the population dynamics of ticks (Norman et al. 2015). In North America, first models and risk assessments were presented as early as the 1980s (Norman et al. 2015) and have been continuously improved until now (Sharareh et al. 2017; Gaff et al. 2020). Unfortunately, a Europe-wide risk assessment for LB is still missing. As listed in Table 2, there are only a few risk maps for selected regions in Europe. These static risk assessments differ in the spatial resolution ranging from administrative district level to $1 \mathrm{~km}^{2}$ or smaller. Generally, the choice of spatial and temporal model resolution determines the degree of accuracy, realism, and general applicability of a risk assessment (Kitron 1998). Although a high spatial and temporal resolution is often desired, the lowest possible resolution is mainly determined by the resolution 
Table 2 Existing maps depicting the risk of human exposure to Borrelia burgdorferi s.l. in European regions. The models are divided in the two approaches based either on infected ticks or on human incidence. Methods and variables are indicated. The latter are grouped into climatic variables (e.g., temperature), soil variables (e.g., land cover, normalized difference vegetation index (NDVI), topographic variables (e.g., altitude), human-related variables (e.g., human population), and host-related variables (e.g., roe deer density).

\begin{tabular}{|c|c|c|c|c|c|c|c|c|}
\hline \multirow[t]{2}{*}{ Risk map depicting } & \multirow[t]{2}{*}{ Country (region) } & \multirow[t]{2}{*}{ Method } & \multicolumn{5}{|c|}{ Explanatory variables } & \multirow[t]{2}{*}{ Reference } \\
\hline & & & $\begin{array}{l}\text { Climatic } \\
\text { variables }\end{array}$ & $\begin{array}{l}\text { Soil } \\
\text { vari- } \\
\text { ables }\end{array}$ & $\begin{array}{l}\text { Topo- } \\
\text { graphic } \\
\text { variables }\end{array}$ & $\begin{array}{l}\text { Human } \\
\text { related vari- } \\
\text { ables }\end{array}$ & $\begin{array}{l}\text { Host } \\
\text { related } \\
\text { variables }\end{array}$ & \\
\hline $\begin{array}{l}\text { Density of infected } \\
\text { ticks }\end{array}$ & $\begin{array}{l}\text { Italy (Province of } \\
\text { Trento) }\end{array}$ & $\begin{array}{l}\text { Tree-based clas- } \\
\text { sification model } \\
\text { with bootstrap } \\
\text { aggregation }\end{array}$ & - & $\mathrm{x}$ & $\mathrm{x}$ & - & $\mathrm{x}$ & Rizzoli et al. (2002) \\
\hline $\begin{array}{l}\text { Density of infected } \\
\text { ticks }\end{array}$ & $\begin{array}{l}\text { Italy (Friuli } \\
\text { Venezia Giulia } \\
\text { region) }\end{array}$ & $\begin{array}{l}\text { Multiple regression } \\
\text { model }\end{array}$ & $\mathrm{x}$ & $\mathrm{x}$ & $\mathrm{x}$ & - & $\mathrm{x}$ & $\begin{array}{l}\text { Altobelli et al. } \\
\text { (2008) }\end{array}$ \\
\hline $\begin{array}{l}\text { Probability of } \\
\text { the presence of } \\
\text { infected ticks }\end{array}$ & Ireland & $\begin{array}{l}\text { Random forests } \\
\text { model }\end{array}$ & $\mathrm{x}$ & $\mathrm{x}$ & $\mathrm{x}$ & - & - & Zintl et al. (2020) \\
\hline $\begin{array}{l}\text { Density of infected } \\
\text { ticks }\end{array}$ & $\begin{array}{l}\text { United Kingdom } \\
\text { (Scotland) }\end{array}$ & $\begin{array}{l}\text { Mechanistic, agent- } \\
\text { based model }\end{array}$ & $\mathrm{x}$ & $\mathrm{x}$ & - & - & $\mathrm{x}$ & Li et al. (2016) \\
\hline Human incidence & Belgium & $\begin{array}{l}\text { Negative binomial } \\
\text { regression model }\end{array}$ & - & $\mathrm{x}$ & - & $\mathrm{x}$ & $\mathrm{x}$ & Linard et al. (2007) \\
\hline Human incidence & Belgium & $\begin{array}{l}\text { Regression trees } \\
\text { model }\end{array}$ & - & $\mathrm{x}$ & - & $\mathrm{x}$ & - & Barrios et al. (2013) \\
\hline $\begin{array}{l}\text { Relative risk for } \\
\text { human Lyme bor- } \\
\text { reliosis }\end{array}$ & $\begin{array}{l}\text { Czech Republic } \\
\text { (Central Bohe- } \\
\text { mian region) }\end{array}$ & $\begin{array}{l}\text { Geographical } \\
\text { information } \\
\text { system (GIS) }\end{array}$ & - & - & - & $\mathrm{x}$ & - & Zeman (1997) \\
\hline
\end{tabular}

of the available predictor variables (e.g., temperature or other key drivers) and/or data on humans, hosts, vectors, and pathogen. In case of LB risk assessments, a map depicting the spatial distribution on a regional scale would be realistic with a spatial resolution of $1-5 \mathrm{~km}$. A risk map with comparable resolution was recently published by Walter et al. (2020) for TBE, the most common viral tick-borne disease (TBD) in Europe. Nevertheless, simulations, prediction, and/or risk assessments for LB are important tools for decision-makers. Such tools can support the identification of areas constituting a risk, the implementation of streamlined pathogen control methods, or help to increase disease awareness and encourage people to take preventive actions against tick bites (Norman et al. 2015). Recent analysis concluded that especially targeted awareness-based strategies are both cost-effective and significantly reduce the number of LB cases (Sharareh et al. 2017, Behler et al. 2020).

\section{Factors that might contribute in an increase of LB cases}

The risk to become infected with Lyme borreliae largely depends on contact of humans with vectors infected with the pathogen (Borchers et al. 2015). If the vector, potential reservoir hosts, and the human population expand their range, it is strongly suggested that $\mathrm{LB}$ will be an important public health issue in the future (de Keukeleire et al. 2016; Stone et al. 2017; Petrulionienè et al. 2020). What are the key drivers of distribution expansion and an increasing infection risk for humans? Encroachment of humans into natural habitats is one factor that increases the risk of infection. As known from other VBD, the vector-host-pathogen transmission cycle is a highly complex ecosystem in which ticks, Borrelia, and vertebrate hosts interact at various environmental conditions with each other. Consequently, each change driven either by natural phenomena or by human interventions directly affects the ecological balance and thus the potential of the pathogen to come into contact with humans (Patz et al. 2000; Hartemink et al. 2015; EstradaPeña et al. 2017). Anthropogenic impacts such as climate change, land cover changes, or geographical expansion of hosts (also incidental or dead-end hosts such as humans) are considered to be the main reasons for the increase in tick abundance, distribution of ticks in new habitats, and therefore the risk of infection (Mysterud et al. 2014; Li et al. 2019; Diuk-Wasser et al. 2020). As both, Ixodes ticks as well as Borrelia, depend on complex ecological systems, one needs to ask the question why are Ixodes abundance and Borrelia prevalence are increasing when there is a general consent that most ecosystems are in a dire condition 
(Wagner et al. 2021)? Different species may respond differently to environmental changes and some may even increase (at least temporarily). Insect decline can be taken as a proxy for the general decline of ecosystems. Several reservoir hosts such as hedgehogs or other insectivores depend on insects as major food source, and thus, if these hosts disappear as a consequence of insect decline, it may have a knock-on effect on Borrelia and may lead to a reduction or shifts in Borrelia species composition. For some European bird populations, stable or increasing numbers have been recorded while others appear to dwindle (Staneva and Burfield 2017). How these biotic and abiotic factors may impact tick ecology and expansion is currently difficult to assess.

\section{Impact of climate change on tick ecology}

Ticks are poikilothermic organisms; thus, rising temperatures have an enormous impact on all stages of the tick's life cycle and their distribution as well as on their associated microorganisms and pathogens and hosts (Perez et al. 2016; Alkishe et al. 2017). Within the last decades, climate change led not only to an increased annual mean temperature of about $0.7^{\circ} \mathrm{C}$; it is expected to rise an additional $1.1^{\circ} \mathrm{C}$ within the next 100 years (Patz et al. 2000). Climate change also results in more extreme weather events (e.g., local flooding, droughts, storms) (EPA 2021) with an unknown effect on eco-systems.

These rising temperatures greatly affect the phenology of ticks as they might extend their seasonal activity and feeding behavior in spring and fall in some regions while in other regions conditions may become too hot and dry (Alkishe et al. 2017; Petrulionienè et al. 2020). It is assumed that $I$. ricinus could prolong their usual activity period from March to November until January due to milder winters (Gray 2008; Gray et al. 2009; Porretta et al. 2013). Besides that, a climatic shift to milder winters can lead to an expanding of the tick's distribution to both, northern latitudes and higher altitudes (Semenza and Menne 2009; Korotkov et al. 2015; Semenza and Suk 2018; Bouchard et al. 2019). A study from the Czech Republic showed that I. ricinus had shifted their distribution level from about 700 to $800 \mathrm{~m}$ to 1,100 m.a.s.l over the last 2 decades, and in Switzerland, ticks can be found at altitudes up to 1,450 m.a.s.l. (Cotty et al 1986; Materna et al. 2008). Studies from Sweden and Norway reported also a shift of the northern distribution level of I. ricinus (Jaenson et al. 2012; Jore et al. 2014). On the other hand, changes in temperature and moisture due to climate change may have an impact on woodlands, trees, or other natural habitats that are important for the hosts. Such changes may have a yet unpredicted outcome on the ecology in various regions in Europe. In addition, lower summer precipitation combined with higher summer temperatures as suggested for the southernmost distribution range of
I. ricinus might have a negative effect on the survival of this tick species and thus decreases the risk of infection (Gray et al. 2009; Porretta et al. 2013). Furthermore, higher temperatures might also improve the tick's and/or host survival and reproduction conditions resulting in higher tick and/or host densities, possible leading to more infected ticks and/or hosts (Mills et al. 2010). Another important factor for the development of ticks is humidity as they need up to $80 \%$ relative humidity to survive during the off-host period (Gray et al. 2009; Medlock et al. 2013). Changes in temperature impacts the hydrological cycle as warmer air can hold more moisture than cooler air, resulting in more precipitation events providing suitable humidity conditions for the tick's survival. However, this can also result in reduced soil moisture in case of more evaporation which might affect ticks negatively (Patz et al. 2000). Another effect of expanding milder temperatures is the extension of vegetation periods which also affects the abundance of ticks and hosts as well as the pathogen (Menzel and Fabian 1999; Jaenson and Lindgren 2011). As shown in Sweden, milder climate favors the production of plant biomass in particular deciduous vegetation which might have a positive effect on mammals, roe deer, or birds known to serve as hosts for $I$. ricinus (Jaenson et al. 2009; Jaenson and Lindgren 2011).

It is also assumed that the development and replication of a pathogen within an ectothermic vector is faster at higher temperatures, and therefore, the risk of transmission may increase (Caminade et al. 2019; Bouchard et al. 2019). On the other hand, there are physiological constraints for the tick as molting from one stage to the next requires times for diapauses which cannot be shortened.

\section{Conservation management}

Ticks are restricted to habitats with moderate to high precipitation and an adequate vegetation cover that holds humidity during dry periods (Lindgren et al. 2000; Gray et al. 2009; Medlock et al. 2013). Therefore, vegetation characteristics are very important for the tick's distribution and survival (Lindgren and Jaenson 2006). Additionally, the local composition of potential hosts as well as their abundance influences the number of infected ticks (Medlock et al. 2013; Rudenko et al. 2014). Thus, conservation management activities affecting land use by, e.g., woodland regeneration or urban greening as well as wildlife management strategies to control invasive and native host populations will influence the dynamic system of VBD (Millins et al. 2017). Another worrying development from an ecological perspective is fragmentation of landscapes as these splits animals into small and isolated populations making them vulnerable to species losses which may have uncertain consequences on VBD systems. Moreover, species characterized by high population densities and being active at a low range like small 
rodents could benefit from the lack of predators or competitors. Previous studies in the USA and elsewhere showed that fragmented forests smaller than 2 ha tend to harbor high densities of white-footed mice combined with low densities of large vertebrate hosts (e.g., deer) resulting in a high density of infected nymphal ticks (Patz et al. 2000; Allan et al. 2003). In such cases, woodland regeneration could result in a higher biodiversity and thus in a significant reduction of Borrelia-infected ticks (Younger 2016). Another factor which may influence the potential risk of acquiring Borrelia is ongoing urban greening with the creation and establishment of protected and recreational areas as it could increase the likelihood of human-tick contact (Millins et al. 2017). However, ongoing urbanization and increases in artificial land cover provide poor settings for wildlife that can serve as hosts for ticks (European Environment Agency (EEA) 2011).

Wildlife fluctuation, either human made or naturally induced, also influences the distribution of hosts and, thus, affects tick abundance and infection risk (de Keukeleire et al. 2016). Although deer are known to act as dead-end hosts for Borrelia, they are an important host for adult female ticks laying eggs afterward (Perkins et al. 2006; Millins et al. 2017; Hofmeester et al. 2017). Changes in land use and climate as well as the expansion of non-native deer species have led, in some parts of the world, to an expansion of the range and population size of deer. (Newson et al. 2012). Because natural predators have decreased or are completely absent due to human's activity, in many countries, deer are generally controlled by culling or fencing for forestry and crop protection, but there is also a growing interest in using these strategies to control tick populations and thus the incidence of TBD (Gilbert et al. 2012). Studies examining the effects of deer control on the tick population revealed that the reduction of the deer population through culling or fencing also reduced the incidence of ticks, but in some cases, it led to an increased number of ticks in small areas of exclusion (e.g., Gilbert et al. 2012; Perkins et al. 2006; Hofmeester et al. 2017). Beside deer, smaller vertebrate hosts such as the invasive Siberian chipmunk (Tamias sibiricus barberi) should be controlled because of the high prevalence of Borrelia-infected animals that might enhance the infection rate of feeding ticks more than native rodent species (Marsot et al. 2013; Millins et al. 2017; Mori et al. 2018). Other aspects of wildlife management like winter feeding of deer seems to play a tangential role as the benefits of these measures for deer are not clear (Petersen and Messmer 2011).

\section{Changes in human behavior: outdoor activity and self-protection}

Beside biotic and abiotic factors affecting vectors and reservoir hosts, an additional aspect leading to a higher risk for humans to get infected with LB includes the frequency of contact between humans and infected ticks (Jaenson et al. 2012). Due to milder temperatures in Europe, the time humans spend on outdoor or recreational activities (e.g., forestry works, berry and mushroom picking, biking, and hiking) have increased. People who are exposed to ticks during outdoor activity have a higher risk to become infected; thus, it has been recommended that wearing long clothes and using tick repellents will reduce the risk of tick bites (Petrulionienè et al. 2020). As ticks feed for several days on their host, the time of attachment could be also important for the personal risk assessment. Mice infection studies showed that transmission of Borrelia occurs not before 24h but there are no reliable data for humans so far (Piesman 1993; Hojgaard et al. 2008). Thus, an increased awareness of getting "attacked" by ticks and inspecting the body for attached ticks could prevent transmission of the pathogens (Kahl et al. 1998; des Vignes et al. 2001).

\section{Conclusion}

Lyme Borreliosis is the most prevalent VBD in the Northern Hemisphere, but the current knowledge about the complex interaction between diverse pathogen (B. burgdorferi s.l. complex) and vectors (I. ricinus, $I$. persulcatus) as well as different reservoir and non-reservoir hosts is still incomplete. Additionally, epidemiological data for all European countries are hitherto largely fragmented, and inconsistent reporting systems and case definitions make a European-wide evaluation of LB difficult. Due to anthropogenic-driven environmental changes, the occurrence of ticks increases in many areas in Europe although seroprevalence studies do not support an increase in exposure of the human population to Borrelia. Therefore, to significantly increase scientific knowledge, it is essential to more diligently scrutinize the biology of this complex eco-epidemiological system and human LB case numbers. Data about the actual burden of this disease are undoubtedly needed for health authorities to implement and improve surveillance and control measures, in particular in the light that no vaccine is currently available.

Acknowledgements We thank Dr. Volker Fingerle and Dr. Olaf Kahl for critical reading the manuscript and their very helpful comments. The present review is also a product of the LOEWE Centre for Translational Biodiversity Genomics (LOEWE-TBG; AS) and the LOEWE Centre DRUID (Novel Drug Targets against Poverty-related and Neglected Tropical Infectious Diseases; PK) as parts of the "LOEWELandes-Offensive zur Entwicklung Wissenschaftlich-ökonomischer Exzellenz" programme of Hesse's Ministry of Higher Education, Research, and the Arts. 
Funding Open Access funding enabled and organized by Projekt DEAL. AS was funded by the LOEWE Centre for Translational Biodiversity Genomics (LOEWE-TBG) as part of the "LOEWE-LandesOffensive zur Entwicklung Wissenschaftlich-ökonomischer Exzellenz" programme of Hesse's Ministry of Higher Education, Research, and the Arts, and PK was funded by the LOEWE Centre DRUID (Novel Drug Targets against Poverty-related and Neglected Tropical Infectious Diseases).

\section{Availability of data and material Not applicable}

Code availability Not applicable

\section{Declarations}

Ethics approval Not applicable

Consent to participate Not applicable

Consent for publication Not applicable

Conflict of interest The authors declare no competing interests.

Open Access This article is licensed under a Creative Commons Attribution 4.0 International License, which permits use, sharing, adaptation, distribution and reproduction in any medium or format, as long as you give appropriate credit to the original author(s) and the source, provide a link to the Creative Commons licence, and indicate if changes were made. The images or other third party material in this article are included in the article's Creative Commons licence, unless indicated otherwise in a credit line to the material. If material is not included in the article's Creative Commons licence and your intended use is not permitted by statutory regulation or exceeds the permitted use, you will need to obtain permission directly from the copyright holder. To view a copy of this licence, visit http://creativecommons.org/licenses/by/4.0/.

\section{References}

Afzelius A (1921) Erythema chronicum migrans. Acta Derm Venereol. 2:120-125

Alkishe AA, Peterson AT, Samy AM (2017) Climate change influences on the potential geographic distribution of the disease vector tick Ixodes ricinus. PLoS One 12:e0189092. https://doi.org/10.1371/ journal.pone.0189092

Allan BF, Keesing F, Ostfeld RS (2003) Effect of forest fragmentation on Lyme disease risk. Conserv Biol 17:267-272. https://doi.org/ 10.1046/j.1523-1739.2003.01260.x

Altobelli A, Boemo B, Mignozzi K, Bandi M, Floris R et al (2008) Spatial Lyme borreliosis risk assessment in north-eastern Italy. Int J Med Microbiol 298:125-128. https://doi.org/10.1016/j. ijmm.2008.05.005

Anderson C, Brissette CA (2021) The brilliance of Borrelia: mechanisms of host immune evasion by Lyme disease-causing spirochetes. Pathogens 10:281. https://doi.org/10.3390/pathogens1 0030281

Anderson JF, Magnarelli LA, LeFebvre RB, Andreadis TG, McAninch JB et al (1989) Antigenically variable Borrelia burgdorferi isolated from cottontail rabbits and Ixodes dentatus in rural and urban areas. J Clin Microbiol 27:13-20. https://doi.org/10.1128/ jcm.27.1.13-20.1989
Anguita J, Hedrick MN, Fikrig E (2003) Adaptation of Borrelia burgdorferi in the tick and the mammalian host. FEMS Microbiol Rev 27:493-504. https://doi.org/10.1016/S0168-6445(03)00036-6

Baranton G, Postic D, Saint Girons I, Boerlin P, Piffaretti JC et al (1992) Delineation of Borrelia burgdorferi sensu stricto, Borrelia garinii sp. nov., and group VS461 associated with Lyme borreliosis. Int J Syst Bacteriol 42:378-383. https://doi.org/10. 1099/00207713-42-3-378

Barbour AG (1984) Isolation and cultivation of Lyme disease spirochetes. Yale J Biol Med 57:521-525

Barrios JM, Verstraeten WW, Maes P, Aerts JM, Farifteh J et al (2013) Relating land cover and spatial distribution of nephropathia epidemica and Lyme borreliosis in Belgium. Int J Environ Health Res 23:132-54. https://doi.org/10.1080/09603123.2012.708918

Behler RP, Sharareh N, Whetten JS, Sabounchi NS (2020) Analyzing the cost-effectiveness of Lyme disease risk reduction approaches. J Public Health Policy 41:155-169. https://doi.org/10.1057/ s41271-020-00219-0

Berglund J, Eitrem R, Ornstein K, Lindberg A, Ringér A et al (1995) An epidemiologic study of Lyme disease in southern Sweden. N Engl J Med 333:1319-1327. https://doi.org/10.1056/NEJM1 99511163332004

Boehnke D, Brugger K, Pfäffle M, Sebastian P, Norra S et al (2015) Estimating Ixodes ricinus densities on the landscape scale. Int $\mathbf{J}$ Health Geogr 14:23. https://doi.org/10.1186/s12942-015-0015-7

Borchers AT, Keen CL, Huntley AC, Gershwin ME (2015) Lyme disease: a rigorous review of diagnostic criteria and treatment. $\mathrm{J}$ Autoimmun 57:82-115. https://doi.org/10.1016/j.jaut.2014.09. 004

Bouchard C, Dibernardo A, Koffi J, Wood H, Leighton PA et al (2019) Increased risk of tick-borne diseases with climate and environmental changes. Can Commun Dis Rep 45:83-89. https://doi.org/ 10.14745/ccdr.v45i04a02

Bregnard C, Rais O, Voordouw MJ (2020) Climate and tree seed production predict the abundance of the European Lyme disease vector over a 15-year period. Parasit Vectors 13:408. https://doi. org/10.1186/s13071-020-04291-z

Bregnard C, Rais O, Voordouw MJ (2021) Masting by beech trees predicts the risk of Lyme disease. Parasit Vectors 14:168. https:// doi.org/10.1186/s13071-021-04646-0

Brugger K, Boehnke D, Petney T, Dobler G, Pfeffer M et al (2016) A density map of the tick-borne encephalitis and Lyme borreliosis vector Ixodes ricinus (Acari: Ixodidae) for Germany. J Med Entomol 53:1292-1302. https://doi.org/10.1093/jme/tjw116

Brugger K, Walter M, Chitimia-Dobler L, Dobler G, Rubel F (2018) Forecasting next season's Ixodes ricinus nymphal density: the example of southern Germany 2018. Exp Appl Acarol 75:281288. https://doi.org/10.1007/s10493-018-0267-6

Burgdorfer W, Barbour AG, Hayes SF, Benach JL, Grunwaldt E et al (1982) Lyme disease - a tick borne spirochetosis? Science 216:1317-1319. https://doi.org/10.1126/science.7043737

Bykowski T, Woodman ME, Cooley AE, Brissette CA, Brade V et al (2007) Coordinated expression of Borrelia burgdorferi complement regulator-acquiring surface proteins during the Lyme disease spirochete's mammal-tick infection cycle. Infect Immun 75:4227-4236. https://doi.org/10.1128/IAI.00604-07

Caine JA, Coburn J (2015) A short-term Borrelia burgdorferi infection model identifies tissue tropisms and bloodstream survival conferred by adhesion proteins. Infect Immun 83:3184-3194. https://doi.org/10.1128/IAI.00349-15

Caine JA, Lin Y-P, Kessler JR, Sato H, Leong JM et al (2017) Borrelia burgdorferi outer surface protein $\mathrm{C}(\mathrm{OspC})$ binds complement component $\mathrm{C} 4 \mathrm{~b}$ and confers bloodstream survival. Cell Microbiol 19:e12786. https://doi.org/10.1111/cmi.12786 
Canica MM, Nato F, du Merle L, Mazie JC, Baranton G et al (1993) Monoclonal antibodies for identification of Borrelia afzelii sp. nov. associated with late cutaneous manifestations of Lyme borreliosis. Scand J Infect Dis 25:441-448. https://doi.org/10.3109/ 00365549309008525

Caminade C, McIntyre KM, Jones AE (2019) Impact of recent and future climate change on vector-borne diseases. Ann N Y Acad Sci 1436:157-173. https://doi.org/10.1111/nyas.13950

Carrol JA, Garon CF, Schwan TG (1999) Effects of environmental pH on membrane proteins in Borrelia burgdorferi. Infect Immun 67:3181-3187. https://doi.org/10.1128/IAI.67.7.3181-3187.1999

Casjens S, Palmer N, van Vugt R, Huang WM, Stevenson B et al (2000) A bacterial genome in flux: the twelve linear and nine extrachromosomal DNAs in an infectious isolate of the Lyme disease spirochete Borrelia burgdorferi. Mol Microbiol 35:490-516. https:// doi.org/10.1046/j.1365-2958.2000.01698.x

Casjens SR, Fraser-Liggett CM, Mongodin EF, Qiu WG, Dunn JJ et al (2011) Whole genome sequence of an unusual Borrelia burgdorferi sensu lato isolate. J Bacteriol 193:1489-1490. https://doi.org/ 10.1128/JB.01521-10

Centre for Disease Control and Prevention, CDC (2019) Case numbers of Lyme Disease in the United States of America. Available online: https://www.cdc.gov/lyme/stats/graphs.html?CDC_AA_ refVal. (Accessed 10.06.2021)

Centre for Disease Control and Prevention (2021) Lyme disease. Available online: https://www.cdc.gov/lyme/index.html (accessed 10.06.2021)

Chaconas G, Castellanos M, Verhey TB (2020) Changing of the guard: how Lyme disease spirochete subverts the host immune response. J Biol Chem 295:301-313. https://doi.org/10.1074/jbc.REV119. 008583

Chu C-Y, Liu W, Jiang B-G, Wang D-M, Jiang W-J et al (2008) Novel genospecies of Borrelia burgdorferi sensu lato from rodents and ticks in southwestern China. J Clin Microbiol 46:3130-3133. https://doi.org/10.1128/JCM.01195-08

Coburn J, Garcia B, Hu LT, Jewett MW, Kraiczy P et al (2020) Lyme disease pathogenesis. Curr Issues Mol Biol 42:473-518. https:// doi.org/10.21775/cimb.042.473

Coipan EC, Jahfari S, Fonville M, Maassen CB, van der Giessen J et al (2013) Spatiotemporal dynamics of emerging pathogens in questing Ixodes ricinus. Front Cell Infect Microbiol 3:36. https:// doi.org/10.3389/fcimb.2013.00036

Cotty A, Aeschlimann A, Schneeberger S (1986) Distribution et fluctuation de populations d'Ixodes ricinus (L.), Haemaphysalis punctata (Can.\&Fanz.) et Dermacentor marginatus (Sulzer) (Acarina, Ixodoidea) en Suisse. Mitt Schweiz Entomol Ges 59:139-150

Cuellar J, Dub T, Sane J, Hytönen J (2019) Seroprevalence of Lyme borreliosis in Finland 50 years ago. Clin Microbiol Infect 26:632-636. https://doi.org/10.1016/j.cmi.2019.10.003

Cutler SJ, Vayssier-Taussat M, Estrada-Peña A, Potkonjak A, Mihalca $\mathrm{AD}$ et al (2021) Tick-borne diseases and co-infection: current considerations. Ticks Tick Borne Dis 12:101607. https://doi.org/ 10.1016/j.ttbdis.2020.101607

de Keukeleire M, Robertz A, Kabamba B, Dion E, Luyasu V et al (2016) Individual and environmental factors associated with the seroprevalence of Borrelia burgdorferi in Belgian farmers and veterinarians. Infect Ecol Epidemiol 6:32793. https://doi.org/10. 3402/iee.v6.32793

Dessau RB, van Dam AP, Fingerle V, Gray J, Hovius JW et al (2018) To test or not to test? Laboratory support for the diagnosis of Lyme borreliosis: a position paper of ESGBOR, the ESCMID study group for Lyme borreliosis. Clin Microbiol Infect 24:118124. https://doi.org/10.1016/j.cmi.2017.08.025

des Vignes F, Piesman J, Heffernan R, Schulze TL, Stafford KC et al (2001) Effect of tick removal on transmission of Borrelia burgdorferi and Ehrlichia phagocytophila by Ixodes scapularis nymphs. J Infect Dis 183:773-778. https://doi.org/10.1086/ 318818

Diuk-Wasser MA, Hoen AG, Cislo P, Brinkerhoff R, Hamer SA et al (2012) Human risk of infection with Borrelia burgdorferi, the Lyme disease agent, in eastern United States. Am J Trop Med Hyg 86:320-327. https://doi.org/10.4269/ajtmh.2012.11-0395

Diuk-Wasser MA, VanAcker MC, Fernandez MP (2020) Impact on land use changes and habitat fragmentation on the eco-epidemiology of tick- borne diseases. J Med Entomol. https://doi.org/ 10.1093/jme/tjaa209

Dsouli N, Younsi-kabachii H, Postic D, Nouira S, Gern L et al (2006) Reservoir role of lizard Psammodromus algirus in transmission cycle of Borrelia burgdorferi sensu lato (Spirochaetaceae) in Tunisia. J Med Entomol 43:737-742. https://doi.org/10.1603/ 0022-2585(2006)43[737:rrolpa]2.0.co;2

Eisen L, Lane RS (2002) Vectors of Borrelia burgdorferi sensu lato. In: Gray JS, Kahl O, Lane RS, Stanek G (eds) Lyme borreliosis: biology, epidemiology and control. CABI Publishing, Oxon, UK, pp 91-115

Eisen L (2020) Vector competence studies with hard ticks and Borrelia burgdorferi sensu lato spirochetes: a review. Ticks Tick Borne Dis 11:101359. https://doi.org/10.1016/j.ttbdis.2019.101359

Ekner A, Dudek K, Sajkowska Z, Majláthová V, Majláth, et al (2011) Anaplasmataceae and Borrelia burgdorferi sensu lato in the sand lizard Lacerta agilis and co-infection of these bacteria in hosted Ixodes ricinus ticks. Parasites Vectors 4:182. https://doi.org/10. 1186/1756-3305-4-182

Eldin C, Raffetin A, Bouiller K, Hansmann Y, Roblot F et al (2019) Review of European and American guidelines for the diagnosis of Lyme borreliosis. Med Mal Infect 49:121-132. https://doi.org/ 10.1016/j.medmal.2018.11.011

Enkelmann J, Böhmer M, Fingerle V, Siffczyk C, Werber D et al (2018) Incidence of notified Lyme borreliosis in Germany 2013-2017. Sci Rep 8:14976. https://doi.org/10.1038/ s41598-018-33136-0

Environmental Protection Agency, EPA (2021) Climate change indicators: weather and climate. Available online: https:// www.epa.gov/climate-indicators/weather-climate (accessed 15.06.2021)

Estrada-Peña A, Farkas R, Jaenson TGT, Koenen F, Madder M et al. (2013) Association of environmental traits with the geographic ranges of ticks (Acari: Ixodidae) of medical and veterinary importance in the western Palearctic. A digital data set. Exp Appl Acarol 59:351-366 https://doi.org/10.1007/ s10493-012-9600-7

Estrada-Peña A, Mihalca AD, Petney TN (2017) Ticks of Europe and North Africa - a guide to species identification. Springer International Publishing, 404 pp., https://doi.org/10.1007/ 978-3-319-63760-0

European Centre for Disease Prevention and Control (ECDC) (2014) Lyme borreliosis in Europe. Available online: https://www. ecdc.europa.eu/sites/portal/files/media/en/healthtopics/vectors/ world-health-day-2014/Documents/factsheet-lyme-borreliosis. pdf (accessed 10.06.2021)

European Environment Agency (EEA) (2011) EEA Report No2/2011 - Landscape fragmentation in Europe. Available online: https:// www.eea.europa.eu/publications/landscape-fragmentation-ineurope (accessed 27.10.2021)

Fraser CM, Casiens S, Huang WM, Sutton GG, Clayton R et al (1997) Genomic sequence of a Lyme disease spirochaete, Borrelia burgdorferi. Nature 390:580-586. https://doi.org/10.1038/37551

Fryland L, Wilhelmsson P, Lindgren P-E, Nyman D, Ekerfelt C (2011) Low risk of developing Borrelia burgdorferi infection in the south-east of Sweden after being bitten by a Borrelia burgdorferi - infected tick. Int J Infect Dis 15:e174-181. https://doi.org/ 10.1016/j.ijid.2010.10.006 
Fukunaga M, Hamase A, Okada K, Nakao M (1996) Borrelia tanukii sp. nov. and Borrelia turdae sp. nov. found from ixodid ticks in Japan: rapid species identification by $16 \mathrm{~S}$ rRNA gene-targeted PCR analysis. Microbiol Immunol 40:877-881. https://doi.org/ 10.1111/j.1348-0421.1996.tb01154.x

Gaff H, Eisen RJ, Eisen L, Nadolny R, Bjork J et al (2020) LYMESIM 2.0: an updated simulation of blacklegged tick (Acari: Ixodidae) population dynamics and enzootic transmission of Borrelia burgdorferi (Spirochaetales: Spirochaetaceae). J Med Entomol 57:715-727. https://doi.org/10.1093/jme/tjz252

Garcia BL, Zhi H, Wager B, Höök M, Skare JT (2016) Borrelia burgdorferi BBK32 inhibits the classical pathway by blocking activation of the $\mathrm{C} 1$ complement complex. PLoS Pathog 12:e1005404. https://doi.org/10.1371/journal.ppat.1005404

Gern L, Siegenthaler M, Hu CM, Leuba-Garcia S, Humair PF et al (1994) Borrelia burgdorferi in rodents (Apodemus flavicollis and $A$. sylvaticus): duration and enhancement of infectivity for Ixodes ricinus ticks. Eur J Epidemiol 10:75-80. https://doi.org/ 10.1007/BF01717456

Gern L, Rouvinez E, Toutoungi LN, Godfroid E (1997) Transmission cycles of Borrelia burgdorferi sensu lato involving Ixodes ricinus and/or I. hexagonus ticks and the European hedgehog, Erinaceus europaeus, in suburban and urban areas in Switzerland. Folia Parasitol (Praha) 44:309-314

Gern L, Estrada-Peña A, Frandsen F, Gray JS, Jaenson TG et al (1998) European reservoir hosts of Borrelia burgdorferi sensu lato. Zentralbl Bakteriol 287:196-204. https://doi.org/10.1016/s09348840(98)80121-7

Gern L, Humair P-F (2002) Ecology of Borrelia burgdorferi sensu lato in Europe. In: Gray JS, Kahl O, Lane RS, Stanek G (eds) Lyme borreliosis: biology, epidemiology and control. CABI Publishing, Oxon, UK, pp 149-174

Gilbert L, Maffey GL, Ramsay SL, Hester AJ (2012) The effect of deer management on the abundance of Ixodes ricinus in Scotland. Ecol Appl 22:658-667. https://doi.org/10.2307/41416790

Glatz M, Resinger A, Semmelweis K, Ambros-Rudolph CM, Müllegger RR (2015) Clinical spectrum of skin manifestations of Lyme Borreliosis in 204 children in Austria. Acta Derm Venereol 95:565-571. https://doi.org/10.2340/00015555-2000

Gocko et al (2019) Lyme borreliosis and other tick-borne diseases. Guidelines from the French scientific societies [in French]. Med Mal Infect 49:296-317. https://doi.org/10.1016/j.medmal. 2019.05.006

Gray JS, Kahl O, Robertson JN, Daniel M, Estrada-Peña A et al (1998) Lyme borreliosis habitat assessment. Zentralbl Bakteriol 287:211-228. https://doi.org/10.1016/s0934-8840(98) 80123-0

Gray JS (2008) Ixodes ricinus seasonal activity: implications of global warming indicated by revisiting tick and weather data. Int J Med Microbiol 298:19-24. https://doi.org/10.1016/j. ijmm.2007.09.005

Gray JS, Dautel H, Estrada-Peña A, Kahl O, Lindgren E (2009) Effectes of climate change on ticks and tick-borne diseases in Europe. Interdiscip Perspect Infect Dis 2009:593232. https:// doi.org/10.1155/2009/593232

Gray JS, Kahl O, Lane RS, Levin ML, Tsao JI (2016) Diapause in ticks of the medically important Ixodes ricinus species complex. Ticks Tick Borne Dis 7:992-1003. https://doi.org/10. 1016/j.ttbdis.2016.05.006

Guglielmone AA, Robbins RG, Apanaskevich DA, Petney TN, Estrada-Peña A et al. (2014) The hard ticks of the world (Acari: Ixodida: Ixodidae). Springer, Dordrecht, 738 pp., https://doi. org/10.1007/978-94-007-7497-1

Hallström T, Siegel C, Mörgelin M, Kraiczy P, Skerka C et al. (2013) CspA from Borrelia burgdorferi inhibits the terminal complement pathway. mBio 4:e00481-e00513 https://doi.org/ 10.1128/mBio.00481-13

Hammerschmidt C, Koenigs A, Siegel C, Hallström T, Skerka C et al (2014) Versatile roles of CspA orthologs in complement inactivation of serum-resistant Lyme disease spirochetes. Infect Immun 82:380-92. https://doi.org/10.1128/IAI.01094-13

Hammerschmidt C, Klevenhaus Y, Koenigs A, Hallström T, Fingerle V et al (2016) BGA66 and BGA71 facilitate complement resistance of Borrelia bavariensis by inhibiting assembly of the membrane attack complex. Mol Microbiol 99:407-24. https:// doi.org/10.1111/mmi.13239

Hanincová K, Kurtenbach K, Diuk-Wasser M, Brei B, Fish D (2006) Epidemic spread of Lyme borreliosis, northeastern United States. Emerg Infect Dis 12:604-611. https://doi.org/10.3201/ eid1204.051016

Hansmann Y (2009) Treatment and prevention of Lyme disease. Lipsker D and Jaulhac B (eds): Lyme borreliosis. Curr probl Dermatol Karger (Basel) 37:111-129 https://doi.org/10.1159/000213071

Hart T, Nguyen NTT, Nowak NA, Zhang F, Linhardt RJ et al (2018) Polymorphic factor H-binding activity of CspA protects Lyme borreliae from the host complement in feeding ticks to facilitate tick-to-host transmission. PLoS Pathog 14:e1007106. https://doi.org/10.1371/journal.ppat.1007106

Hart TM, Dupuis AP 2nd, Tufts DM, Blom AM, Starkey SR et al (2021) Host tropism determination by convergent evolution of immunological evasion in the Lyme disease system. PLoS Pathog 17:e1009801. https://doi.org/10.1371/journal.ppat. 1009801

Hartemink N, Vanwambeke SO, Purse BV, Gilbert M, van Dyck H (2015) Towards a resource-based habitat approach for spatial modelling of vector-borne disease risks. Biol Rev 90:1151-1162. https://doi.org/10.1111/brv.12149

Hasle G, Bjune G, Edvardsen E, Jakobsen C, Linnehol B et al (2009) Transport of ticks by migratory passerine birds to Norway. J Parasitol 95:1342-1351. https://doi.org/10.1645/GE-2146.1

Hellenbrand W, Kreusch T, Böhmer MM, Wagner-Wiening C, Dobler $\mathrm{G}$ et al (2019) Epidemiology of Tick-Borne Encephalitis (TBE) in Germany, 2001-2018. Pathogens 29:42. https://doi.org/10. 3390/pathogens8020042

Hellwage J, Meri T, Heikkilä T, Alitalo A, Panelius J et al. (2001) The complement regulator factor $\mathrm{H}$ binds to the surface protein OspE of Borrelia burgdorferi. J Biol Chem 276:8427-8435 https://doi. org/10.1074/jbc.M007994200

Heylen D, de Coninck E, Jansen F, Madder M (2014a) Differential diagnosis of three common Ixodes spp. ticks infesting songbirds of Western Europe: Ixodes arboricola, I. frontalis and I. ricinus. Ticks Tick Borne Dis 5:693-700 https://doi.org/10.1016/j.ttbdis. 2014.05.006

Heylen D, Matthysen E, Fonville M, Sprong H (2014b) Songbirds as general transmitters but selective amplifiers of Borrelia burgdorferi sensu lato genotypes in Ixodes ricinus ticks. Environ Microbiol 16:2859-2868. https://doi.org/10.1111/1462-2920.12304

Heylen D, Fonville M, Docters van Leeuwen A, Stroo A, Duisterwinkel M et al (2017) Pathogen communities of songbird-derived ticks in Europe's low countries. Parasit Vectors 10:497. https://doi.org/ 10.1186/s13071-017-2423-y

Hofmann H, Fingerle V, Hunfeld KP, Huppertz HI, Krause A et al. (2017) Cutaneous Lyme borreliosis: guideline of the German Dermatology Society. Ger Med Sci 15https://doi.org/10.3205/ 000255

Hofmeester TR, Sprong H, Jansen PA, Prins HHT, van Wieren SE (2017) Deer presence rather than abundance determines the population density of the sheep tick, Ixodes ricinus, in Dutch forests. Parasit Vectors 10:433. https://doi.org/10.1186/s13071017.2370-7 
Hojgaard A, Eisen RJ, Piesman J (2008) Transmission dynamics of Borrelia burgdorferi s.s. during the key third day of feeding by nymphal Ixodes scapularis (Acari: Ixodidae). J Med Entomol 45:732-736. https://doi.org/10.1603/0022-2585(2008)45[732: TDOBBS]2.0.CO;2

Hubálek Z (2009) Epidemiology of Lyme borreliosis. Lipsker D and Jaulhac B (eds): Lyme borreliosis, Curr probl Dermatol, Karger), 37:31-50 https://doi.org/10.1159/000213069

Huegli D, Moret J, Rais O, Moosmann Y, Erard P et al (2011) Prospective study on the incidence of infection by Borrelia burgdorferi sensu lato after a tick bite in a highly endemic area of Switzerland. Ticks Tick Borne Dis 2:129-136. https://doi.org/10.1016/j. ttbdis.2011.05.002

Hunfeld KP, Allwinn R, Peters S, Kraiczy P, Brade V (1998) Serologic evidence for tick-borne pathogens other than Borrelia burgdorferi (TOBB) in Lyme borreliosis patients from midwestern Germany. Wien Klin Wochenschr 110:901-8

Huppertz HI, Böhme M, Standaert SM, Karch H, Plotkin SA (1999) Incidence of Lyme borreliosis in the Wurzburg region of Germany. Eur J Clin Microbiol Infect Dis 18:697-703. https://doi. org/10.1007/s100960050381

Hyde JA (2017) Borrelia burgdorferi keeps moving and carries on: a review of borrelial dissemination and invasion. Front Immunol 8:114 https://doi.org/10.3389/fimmu.2017.00114

Indest KJ, Howell JK, Jacobs MB, Scholl-Meeker D, Norris SJ et al (2001) Analysis of Borrelia burgdorferi vlsE gene expression and recombination in the tick vector. Infect Immun 69:70837090. https://doi.org/10.1128/IAI.69.11.7083-7090.2001

Ivanova LB, Tomova A, Gonzalez-Acuna D, Murua R, Moreno CX et al (2014) Borrelia chilensis, a new member of the Borrelia burgdorferi sensu lato complex that extends the range of this genospecies in the Southern Hemisphere. Environ Microbiol 16:1069-1080. https://doi.org/10.1111/1462-2920.12310

Jaenson TG, Tälleklint L (1992) Incompetence of roe deer as reservoirs of the Lyme borreliosis spirochete. J Med Entomol 29:813-817. https://doi.org/10.1093/jmedent/29.5.813

Jaenson TGT, Eisen L, Comstedt P, Mejlon HA, Lindgren E et al (2009) Risk indicators for the tick Ixodes ricinus and Borrelia burgdorferi sensu lato in Sweden. Med Vet Entomol 23:226-237. https://doi.org/10.1111/j.1365-2915.2009.00813.x

Jaenson TGT, Lindgren E (2011) The range of Ixodes ricinus and the risk of contracting Lyme borreliosis will increase northwards when the vegetation period becomes longer. Ticks Tick Borne Dis 2:44-49. https://doi.org/10.1016/j.ttbdis.2010.10.006

Jaenson TGT, Jaenson DGE, Eisen L, Petersson E, Lindgren E (2012) Changes in the geographical distribution and abundance of the tick Ixodes ricinus during the past 30 years in Sweden. Parasit Vectors 5:8. https://doi.org/10.1186/1756-3305-5-8

Johnson RC, Schmid GP, Hyde FW, Steigerwalt AG, Brenner DJ (1984) Borrelia burgdorferi sp. nov.: etiologic agent of Lyme disease. Int J Syst Bacteriol 34:496-497. https://doi.org/10.1099/ 00207713-34-4-496

Jore S, Vanwambeke SO, Viljugrein H, Isaksen K, Kristoffersen AB et al (2014) Climate and environmental change drives Ixodes ricinus geographical expansion at the northern range margin. Parasit Vectors 7:11. https://doi.org/10.1186/1756-3305-7-11

Kahl O (1989) Investigations on the water balance of ticks (Acari, Ixodoidea) in the course of their postembryonic development with special reference to active water vapour uptake in the engorged phases. Dissertation, Free University of Berlin, Germany (in German, $356 \mathrm{pp}$.)

Kahl O, Janetzki-Mittmann C, Gray JS, Jonas R, Stein J et al (1998) Risk of infection with Borrelia burgdorferi sensu lato for a host in relation to the duration of nymphal Ixodes ricinus feeding and the method of tick removal. Zentralbl Bakteriol 287:41-52. https://doi.org/10.1016/s0934-8840(98)80142-4
Kahl O, Gern L, Eisen L, Lane RS (2002) Ecological research on Borrelia burgdorferi sensu lato: terminology and some methodical pitfalls. In: Gray JS, Kahl O, Lane RS, Stanek G (eds) Lyme borreliosis: biology, epidemiology and control. CABI Publishing, Oxon, UK, pp 29-46

Kahl O (2018) Hard ticks as vectors-some basic issues. Wien Klin Wochenschr 130:479-483. https://doi.org/10.1007/ s00508-018-1360-X

Kawabata H, Masuzawa T, Yanagihara Y (1993) Genomic analysis of Borrelia japonica sp. nov. isolated from Ixodes ovatus in Japan. Microbiol Immunol 37:843-848. https://doi.org/10.1111/j.13480421.1993.tb01714.x

Killilea ME, Swei A, Lane RS, Briggs CJ, Ostfeld RS (2008) Spatial dynamics of lyme disease: a review. Ecohealth 5:167-195. https://doi.org/10.1007/s10393-008-0171-3

Kitron U (1998) Landscape ecology and epidemiology of vector-borne diseases: tools for spatial analysis. J Med Entomol 35:435-445. https://doi.org/10.1093/jmedent/35.4.435

Korotkov Y, Kozlova T, Kozlovskaya L (2015) Observations on changes in abundance of questing Ixodes ricinus, castor bean tick, over a 35-year period in the eastern part of its range (Russia, Tula region). Med Vet Entomol 29:129-136. https://doi.org/ 10.1111/mve. 12101

Kraiczy P, Skerka C, Brade V, Zipfel PF (2001) Further characterization of complement regulator-acquiring surface proteins of Borrelia burgdorferi. Infect Immun 69:7800-7809. https://doi.org/ 10.1128/iai.69.12.7800-7809.2001

Kraiczy P (2016) Travelling between two worlds: complement as a gatekeeper for an expanded host range of Lyme disease spirochetes. Vet Sci 3:12. https://doi.org/10.3390/vetsci2020012

Kraiczy P (2016) Hide and seek: how Lyme disease spirochetes overcome complement attack. Front Immunol 7:385. https://doi.org/ 10.3389/fimmu.2016.00385

Kugeler KJ, Eisen RJ (2020) Challenges in predicting Lyme disease risk. JAMA Netw Open 3:e200328. https://doi.org/10.1001/ jamanetworkopen.2020.0328

Kugeler KJ, Am Schwartz, Delorey MJ, Mead PS, Hinckley AF (2021) Estimating the frequency of Lyme disease diagnosis, United States, 2010-2018. Emerg Infect Dis 27:616-619. https://doi.org/10.3201/eid2702.202731

Kung F, Anguita J, Pal U (2013) Borrelia burgdorferi and tick proteins supporting pathogen persistence in the vector. Future Microbiol 8:41-56. https://doi.org/10.2217/fmb.12.121

Kurokawa C, Lynn GE, Pedra JHF, Pal U, Narasimham, et al (2020) Interactions between Borrelia burgdorferi and ticks. Nat Rev Microbiol 18:587-600. https://doi.org/10.1038/ s41579-020-0400-5

Kurtenbach K, Peacey M, Rijpkema SG, Hoodless AN, Nuttall PA et al (1998) Differential transmission of the genospecies of Borrelia burgdorferi sensu lato by game birds and small rodents in England. Appl Environ Microbiol 64:1169-74. https://doi.org/10.1128/AEM.64.4.1169-1174.1998

Kurtenbach K, De Michelis S, Etti S, Schäfer SM, Sewell H-S et al (2002) Host association of Borrelia burgdorferi sensu lato the key role of host complement. Trends Microbiol 10:74-79. https://doi.org/10.1016/s0966-842x(01)02298-3

Kurtenbach K, Schäfer SM, Sewell H-S, Peacey M, Hoodless A et al (2002) Differential survival of Lyme borreliosis spirochetes in ticks that feed on birds. Infect Immun 70:5893-5895. https:// doi.org/10.1128/IAI.70.10.5893-5895.2002

Labandeira-Rey M, Seshu J, Skare JT (2003) The absence of linear plasmid 25 or 28-1 of Borrelia burgdorferi dramatically alters the kinetics of experimental infection via distinct mechanisms. Infect Immun 71:4608-4613. https://doi.org/10.1128/IAI.71.8. $4608-4613.2003$ 
Lantos PM, Rumbaugh J, Bockenstedt LK, Falck-Ytter YT, AgueroRosenfeld ME et al (2021) Clinical practice guidelines by the infectious diseases society of America (IDSA), American Academy of Neurology (AAN), and American College of Rheumatology (ACR): 2020 guidelines for the prevention, diagnosis and treatment of Lyme disease. Clin infect dis 72:e1e48. https://doi.org/10.1093/cid/ciaa1215

Leeflang MMG, Ang CW, Berkhout J, Bijlmer HA, van Bortel W et al (2016) The diagnostic accurancy of serological tests for Lyme borreliosis in Europe: a systematic review and metaanalysis. BMC Infect Dis 16:140. https://doi.org/10.1186/ s12879-016-1468-4

Le Fleche A, Postic D, Girardet K, Peter O, Baranton G (1997) Characterization of Borrelia lusitaniae sp. nov. by $16 \mathrm{~S}$ ribosomal DNA sequence analysis. Int J Syst Bacteriol 47:921-925. https://doi.org/10.1099/00207713-47-4-921

Li S, Gilbert L, Harrison PA, Rounsevell MD (2016) Modelling the seasonality of Lyme disease risk and the potential impacts of a warming climate within the heterogeneous landscapes of Scotland. J R Soc Interface 13:20160140. https://doi.org/10. 1098/rsif.2016.0140

Li S, Gilbert L, Vanwambeke SO, Yu J, Purse BV et al (2019) Lyme disease risk in Europe under multiple uncertain drivers of change. Environ Health Perspect 127:067010. https://doi.org/ 10.1289/EHP4615

Lin T, Gao L, Zhang C, Odeh E, Jacobs MB et al. (2012) Analysis of an ordered, comprehensive STM mutant library in infectious Borrelia burgdorferi: insights into the genes required for mouse infectivity. PLoS One 7:e47532 101371/journal. pone. 0047532

Lin Y-P, Chen Q, Ritchie JA, Dufour NP, Fischer JR et al (2015) Glycosaminoglycan binding by Borrelia burgdorferi adhesin BBK32 specifically and uniquely promotes joint colonization. Cell Microbiol 17:860-75. https://doi.org/10.1111/cmi.12407

Lin Y-P, Diuk-Wasser MA, Stevenson B, Kraiczy P (2020) Complemet Evasion contributes to Lyme borreliae-host associations. Trends Parasitol 36:634-645. https://doi.org/10.1016/j.pt.2020.04.011

Linard C, Lamarque P, Heyman P, Ducoffre G, Luyasu V et al (2007) Determinants of the geographic distribution of Puumala virus and Lyme borreliosis infections in Belgium. Int J Health Geogr 6:15. https://doi.org/10.1186/1476-072X-6-15

Lindgren E, Tälleklint L, Polfeldt T (2000) Impact of climatic change on the northern latitude limit and population density of the disease-transmitting European tick Ixodes ricinus. Environ Health Perspect 108:119-123. https://doi.org/10.1289/ehp.00108119

Lindgren E, Jaenson TGT (2006) Lyme borreliosis in Europe: influences of climate and climate change, epidemiology, ecology and adaptation measures. World health Organization, Regional office for Europe Available at: https://www.euro.who.int/en/publicatio ns/abstracts/lyme-borreliosis-in-europe.-influences-of-climateand-climate-change,-epidemiology,-ecology-and-adaptationmeasures. (accessed: 23.03.2021)

Lohr B, Fingerle V, Norris DE, Hunfeld KP (2018) Laboratory diagnosis of Lyme borreliosis: current state of the art and future perspective. Crit Rev Clin Lab Sci 55:219-245. https://doi.org/10. 1080/10408363.2018.1450353

Lou Y, Wu J (2017) Modeling Lyme disease transmission. Infect Dis Model 2:229-243. https://doi.org/10.1016/j.idm.2017.05.002

Mannelli A, Bertolotti L, Gern L, Gray J (2011) Ecology of Borrelia burgdorferi sensu lato in Europe: transmission dynamics in multi-host systems, influence of molecular processes and effects of climate change. FEMS Microbiol Rev 36:837-861. https://doi. org/10.1111/j.1574-6976.2011.00312.x

Marcinkiewicz AL, Dupuis AP, Zamba-Campero M, Nowak N, Kraiczy $P$ et al (2019) Blood treatment of Lyme borreliae demonstrates the mechanism of CspZ-mediated complement evasion to promote systemic infection in vertebrate hosts. Cell Microbiol 21:e12998. https://doi.org/10.1111/cmi.12998

Marconi RT, Liveris D, Schwartz I (1995) Identification of novel insertion elements, restriction fragment length polymorphism patterns, and discontinuous 23S rRNA in Lyme disease spirochetes: phylogenetic analyses of rRNA genes and their intergenic spacers in Borrelia japonica sp. nov. and genomic group 21038 (Borrelia andersonii sp. nov.) isolates. J Clin Microbiol 33:2427-2434 https://doi.org/10.1128/jcm.33.9.2427.2434.1995

Margos G, Vollmer SA, Cornet M, Garnier M, Fingerle V et al (2009) A new Borrelia species defined by multilocus sequence analysis of housekeeping genes. Environ Microbiol 75:5410-5416. https://doi.org/10.1128/AEM.00116-09

Margos G, Hojgaard A, Lane RS, Cornet M, Fingerle V (2010) Multilocus sequence analysis of Borrelia bissettii strains from North America reveals a new Borrelia species, Borrelia kurtenbachii. Ticks Tick Borne Dis 1:151-158. https://doi.org/10.1016/j.ttbdis. 2010.09.002

Margos G, Vollmer SA, Ogden NH, Fish D (2011) Population genetics, taxonomy, phylogeny and evolution of Borrelia burgdorferi sensu lato. Infect Genet Evol 11:1545-1563. https://doi.org/10.1016/j. meegid.2011.07.022

Margos G, Castillo-Ramírez S, Hoen AG (2012) Phylogeography of Lyme borreliosis-group spirochetes and methicillin-resistant Staphylococcus aureus. Parasitol 139:1952-1965. https://doi. org/10.1017/S0031182012000741

Margos G, Wilske B, Sing A, Hizo-Teufel C, Cao WC et al (2013) Borrelia bavariensis sp. nov. is widely distributed in Europe and Asia. Int J Syst Evol Microbiol 63:4284-4288. https://doi.org/ 10.1099/ijs.0.052001-0

Margos G, Piesman J, Lane RS, Ogden NH, Sing A et al (2014) Borrelia kurtenbachii sp. nov., a widely distributed member of the Borrelia burgdorferi sensu lato species complex in North America. Int J Syst Evol Microbiol 64:128-130. https://doi.org/10.1099/ ijs.0.054593-0

Margos G, Chu CY, Takano A, Jiang BG, Liu W et al (2015) Borrelia yangtzensis sp. nov. a rodent associated species in Asia is related to B. valaisiana. Int J Syst Evol Microbiol 65:3836-3840. https:// doi.org/10.1099/ijsem.0.000491

Margos G, Lane RS, Fedorova N, Koloczek J, Piesman J et al (2016) Borrelia bissettiae sp. nov. and Borrelia californiensis sp. nov. prevail in diverse enzootic transmission cycles. Int J Syst Evol Microbiol 66:1447-1452. https://doi.org/10.1099/ijsem.0.000897

Margos G, Fedorova N, Kleinjan JE, Hartberger C, Schwan TG et al (2017) Borrelia lanei sp. nov. extends the diversity of Borrelia species in California. Int J Syst Evol Microbiol 67:3872-3876. https://doi.org/10.1099/ijsem.0.002214

Margos G, Fingerle V, Reynolds S (2019) Borrelia bavariensis: vector switch, niche invasion, and geographical spread of a tick-borne bacterial parasite. Front Ecol Evol 7:401. https://doi.org/10.3389/ fevo.2019.00401

Margos G, Fedorova N, Becker NS, Kleinjan JE, Marosevic D et al (2020) Borrelia maritima sp. nov., a novel species of the Borrelia burgdorferi sensu lato complex, occupying a basal position to North America species. Int J Syst Evol Microbiol 70:849-856. https://doi.org/10.1099/ijsem.0.003833

Markowicz M, Schötta A-M, Höss D, Kundi M, Schray C et al (2021) Infections with tickborne pathogens after tick bite, Austria, 2015-2018. Emerg Infect Dis 27:1048-1056. https://doi.org/10. 3201/eid2704.203366

Marsot M, Chapuis J-L, Gasqui P, Dozières A, Masséglia S et al (2013) Introduced Siberian chipmunks (Tamias sibiricus barberi) contribute more to Lyme borreliosis risk than native reservoir 
rodents. PLoS One 8:e55377. https://doi.org/10.1371/journal. pone. 0055377

Masuzawa T, Takada N, Kudeken M, Fukui T, Yano Y et al (2001) Borrelia sinica sp. nov., a lyme disease-related Borrelia species isolated in China. Int J Syst Evol Microbiol 51:1817-1824. https://doi.org/10.1099/00207713-51-5-1817

Materna J, Daniel M, Metelka L, Harčarik J (2008) The vertical distribution, density and the development of the tick Ixodes ricinus in mountain areas influenced by climate changes (The Krkonoše Mts., Czech Republic). Int J Med Microbiol 298:25-37. https:// doi.org/10.1016/J.IjMM.2008.05.004

Mead P, Petersen J, Hinckley A (2019) Updated CDC recommendations for serologic diagnosis of Lyme disease. MMWR Morb Mortal Wkly Rep 68:703 https://doi.org/10.15585/mmwr.mm683 2a4

Medlock JM, Hansford KM, Bormane A, Derdakova M, Estrada-Peña A et al (2013) Driving force for changes in geographical distribution of Ixodes ricinus ticks in Europe. Parasites Vectors 6:1. https://doi.org/10.1186/1756-3305-6-1

Menzel A, Fabian P (1999) Growing season extended in Europe. Nature 397:659. https://doi.org/10.1038/17709

Millins C, Gilbert L, Medlock J, Hansford K, Thompson DB et al (2017) Effects of conservation management of landscapes and vertebrate communities on Lyme borreliosis risk in the United Kingdom. Philos Trans R Soc Lond B Biol Sci 372:20160123. https://doi.org/10.1098/rstb.2016.0123

Mills JN, Gage KL, Khan AS (2010) Potential influence of climate change on vector-borne and zoonotic diseases: a review and proposed research plan. Environ Health Perspect 118:1507-1514. https://doi.org/10.1289/ehp.0901389

Mori E, Zozzoli R, Menchetti M (2018) Global distribution and status of introduced Siberian chipmunks Eutamias sibiricus. Mammal Rev 48:139-152. https://doi.org/10.1111/mam.12117

Mühleip JJ, Lin YP, Kraiczy P (2018) Further insights into the interaction of human and animal complement regulator factor $\mathrm{H}$ with viable Lyme disease spirochetes. Front Vet Sci 5:346. https://doi. org/10.3389/fvets.2018.00346

Müller I, Freitag MH, Poggensee G, Scharnetzky E, Straube E et al. (2012) Evaluating frequency, diagnostic quality, and cost of Lyme borreliosis testing in Germany: a retrospective model analysis. J Immunol Res 595427https://doi.org/10.1155/2012/595427

Mygland A, Ljøstad U, Fingerle V, Rupprecht T, Schmutzhard E (2010) EFNS guidelines on the diagnosis and management of European Lyme neuroborreliosis. Eur J Neurol 17:8-16. https://doi.org/10. 1111/j.1468-1331.2009.02862.x

Mysterud A, Hatlegjerde IL, Sørensen OJ (2014) Attachment site selection of life stages of Ixodes ricinus ticks on a main large host in Europe, the red deer (Cervus elaphus). Parasit Vectors 7:510. https://doi.org/10.1186/s13071-014-0510-x

Newson SE, Johnston A, Renwick AR, Baillie SR, Fuller RJ (2012) Modelling large-scale relationships between changes in woodland deer and bird populations. J Appl Ecol 49:278-286. https:// doi.org/10.1111/j.1365-2664.2011.02077.x

Norman RA, Worton AJ, Gilbert L (2015) Past and future perspectives on mathematical models of tick-borne pathogens. Parasitol 143:850-859. https://doi.org/10.1017/S0031182015001523

Norris DE, Johnson BJ, Piesman J, Maupin GO, Clark JL et al (1997) Culturing selects for specific genotypes of Borrelia burgdorferi in an enzootic cycle in Colorado. J Clin Microbiol 35:23592364. https://doi.org/10.1128/jcm.35.9.2359.2364.1997

Norris SJ (2014) vls antigenic variation systems of Lyme disease borrelia: eluding host immunity through both random, segmental gene conversion and framework heterogeneity. Microbiol Spectr 2https://doi.org/10.1128/microbiolspec.MDNA3-0038-2014
Norte AC, Lopes de Carvalho I, Núncio MS, Ramos JA, Gern L (2013) Blackbirds Turdus merula as competent reservoirs for Borrelia turdi and Borrelia valaisiana in Portugal: evidence from a xenodiagnostic experiment. Environ Microbiol Rep 5:604-607. https://doi.org/10.1111/1758-2229.12058

Norte AC, de Carvalho IL, Núncio MS, Araújo M, Matthysen E et al (2020) Getting under the birds' skin: tissue tropism of Borrelia burgdorferi $\mathrm{s} .1$. in naturally and experimentally infected avian hosts. Microb Ecol 79:756-769. https://doi.org/10.1007/ s00248-019-01442-3

Norte AC, Margos G, Becker NS, Ramos JA, Núncio MS et al (2020) Host dispersal shapes the population structure of a tick-borne bacterial pathogen. Mol Ecol 29:485-501. https://doi.org/10. $1111 /$ mec. 15336

Okeyo M, Hepner S, Rollins RE, Hartberger C, Straubinger RK et al (2020) Longitudinal study of prevalence and spatio-temporal distribution of Borrelia burgdorferi sensu lato in ticks from three defined habitats in Latvia, 1999-2010. Environ Microbiol 22:5033-5047. https://doi.org/10.1111/1462-2920.15100

Pal U, Fikrig E (2003) Adaptation of Borrelia burgdorferi in the vector and vertebrate host. Microbes Infect 5:659-666. https://doi.org/ 10.1016/s1286-4579(03)00097-2

Pal U, Li X, Wang T, Montgomery RR, Ramamoorthi N et al (2004) TROSPA, an Ixodes scapularis receptor for Borrelia burgdorferi. Cell 119:457-68. https://doi.org/10.1016/j.cell.2004.10.027

Patz JA, Graczyk TK, Geller N, Vittor AY (2000) Effects of environmental change on emerging parasitic diseases. Int J Parasitol 30:1395-1405. https://doi.org/10.1016/s0020-7519(00)00141-7

Perez G, Bastian S, Agoulon A, Bouju A, Durand A et al. (2016) Effect of landscape features on the relationship between Ixodes ricinus and their small mammal hosts. Parasit Vectors 9:20 10.11.86/ s13071-016-1296-9

Perkins SE, Cattadori IM, Tagliapietra V, Rizzoli AP, Hudson PJ (2006) Localized deer absence leads to tick amplification. Ecology 87:1981-1986. https://doi.org/10.1890/0012-9658(2006) 87[1981:ldaltt]2.0.co;2

Petersen C, Messmer TA (2011) Biological Consequences of winterfeeding of mule deer in developed landscapes in northern Utah. Wildl Soc Bull 35:252-60. https://doi.org/10.1002/wsb.41

Petrulionienė A, Radzišauskienė D, Ambrozaitis A, Čaplinskas S, Paulauskas A et al (2020) Epidemiology of Lyme disease in a highly endemic European zone. Medicina (Kaunas) 56:115. https://doi. org/10.3390/medicina56030115

Piesman (1993) Dynamics of Borrelia burgdorferi transmission by nymphal Ixodes dammini ticks. J Infect Dis 167:1082-1085. https://doi.org/10.1093/infdis/167.5.1082

Pietikainen J, Meri T, Blom AM, Meri S (2010) Binding of the complement inhibitor C4b-binding protein to Lyme disease Borreliae. Mol Immunol 47:1299-1305. https://doi.org/10.1016/j.molimm. 2009.11.028

Porretta D, Mastrantonio V, Amendolia A, Gaiarsa S, Epis S et al (2013) Effects of global changes on the climatic niche of the tick Ixodes ricinus inferred by species distribution modelling. Parasit Vectors 6:271. https://doi.org/10.1186/ 1756-3305-6-271

Postic D, Belfaiza J, Isogai E, Saint Girons I, Grimont PA et al (1993) A new genomic species in Borrelia burgdorferi sensu lato isolated from Japanese ticks. Res Microbiol 144:467-473. https:// doi.org/10.1016/0923-2508(93)90054-6

Postic D, Ras NM, Lane RS, Hendson M, Baranton G (1998) Expanded diversity among Californian Borrelia isolates and description of Borrelia bissettii sp. nov. (formerly Borrelia group DN127). J Clin Microbiol 36:3497-3504. https://doi.org/10.1128/JCM.36. 12.3497-3504.1998 
Postic D, Garnier M, Baranton G (2007) Multilocus sequence analysis of atypical Borrelia burgdorferi sensu lato isolates - description of Borrelia californiensis sp. nov., and genomospecies 1 and 2. Int J Med Microbiol 297:263-271. https://doi.org/10.1016/j. ijmm.2007.01.006

Preac-Mursic V, Wilske B, Schierz G (1986) European Borrelia burgdorferi isolated from humans and ticks culture conditions and antibiotic susceptibility. Zentralbl Bakteriol Mikrobiol Hyg A 263:112-118. https://doi.org/10.1016/s0176-6724(86)80110-9

Pritt BS, Respicio-Kingry LB, Sloan LM, Schriefer ME, Replogle AJ et al (2016) Borrelia mayonii sp. nov., a member of the Borrelia burgdorferi sensu lato complex, detected in patients and ticks in the upper midwestern United States. Int J Syst Evol Microbiol 66:4878-4880. https://doi.org/10.1099/ijsem.0.001445

Purser JE, Lawrenz MB, Caimano MJ, Howell JK, Radolf JD et al (2003) A plasmid-encoded nicotinamidase (PncA) is essential for infectivity of Borrelia burgdorferi in a mammalian host. Mol Microbiol 48:753-764. https://doi.org/10.1046/j.1365-2958. 2003.03452.x

Radolf JD, Caimano MJ, Stevenson B, Hu LT (2012) Of ticks, mice and men: understanding the dual-host lifestyle of Lyme disease spirochaetes. Nat Rev Microbiol 10:87-99. https://doi.org/10. 1038/nrmicro2714

Randolph SE, Craine NG (1995) General framework for comparative quantitative studies on transmission of tick-borne diseases using Lyme borreliosis in Europe as an example. J Med Entomol 32:765-777. https://doi.org/10.1093/jmedent/32.6.765

Randolph SE (1998) Ticks are not insects: consequences of contrasting vector biology for transmission potential. Parasitol Today. 14(5):186-192. https://doi.org/10.1016/s0169-4758(98)01224-1

Rauer S, Kastenbauer S, Hofmann H, Fingerle V, Huppertz HI et al. (2020) Guidelines for diagnosis and treatment in neurology Lyme neuroborreliosis. Ger Med Sci 18: Doc03 https://doi.org/ $10.3205 / 000279$

Rauter C, Hartung T (2005) Prevalence of Borrelia burgdorferi sensu lato genospecies in Ixodes ricinus ticks in Europe: a metaanalysis. Appl Environ Microbiol 71:7203-7216. https://doi.org/10. 1128/AEM.71.11.7203-7216.2005

Ramamoorthi N, Narasimhan S, Pal U, Bao F, Yang XY et al (2005) The Lyme disease agent exploits a tick protein to infect the mammalian host. Nature 436:573-577. https://doi.org/10.1038/ nature 03812

Revel AT, Talaat AM, Norgaard MV (2002) DNA microarray analysis of differential gene expression in Borrelia burgdorferi, the Lyme disease spirochete. Proc Natl Acad Sci USA 99:15621567. https://doi.org/10.1073/pnas.032667699

Richter D, Schlee DB, Allgöwer R, Matuschka F-R (2004) Relationships of a novel Lyme disease spirochete, Borrelia spielmani sp. nov., with its hosts in Central Europe. Appl Environ Microbiol 70:6414-6419. https://doi.org/10.1128/AEM.70.11.64146419.2004

Richter D, Postic D, Sertour N, Livey I, Matuschka FR et al (2006) Delineation of Borrelia burgdorferi sensu lato species by multilocus sequence analysis and confirmation of the delineation of Borrelia spielmanii sp. nov. Int J Syst Evol Microbiol 56:873-881. https://doi.org/10.1099/ijs.0.64050-0

Rizzoli A, Merler S, Furlanello C, Genchi C (2002) Geographical information systems and bootstrap aggregation (bagging) of tree-based classifiers for Lyme disease risk prediction in Trentino Italian Alps. J Med Entomol. 39:485-492. https://doi.org/ 10.1603/0022-2585-39.3.485

Robert Koch Institute (RKI) (2021) Epidemiologisches Bulletin 09/2021. Available online: https://www.rki.de/DE/Content/ Infekt/EpidBull/Archiv/2021/09/Art_01.html;jsessionid=
F5540A118AE6126164DEFB5D12A9C902.internet071 (accessed 11.10.2021)

Rubel F, Brugger K, Chitimia-Dobler L, Dautel H, Meyer-Kayser E et al (2021) Atlas of ticks (Acari: Argasidae, Ixodidae) in Germany. Exp Appl Acarol 84:183-214. https://doi.org/10.1007/ s10493-021-00619-1

Rudenko N, Golovchenko M, Lin T, Gao L, Grubhoffer L et al (2009) Delineation of a new species of the Borrelia burgdorferi sensu lato complex, Borrelia americana sp. nov. J Clin Microbiol 47:3875-3880. https://doi.org/10.1128/JCM.01050-09

Rudenko N, Golovchenko M, Grubhoffer L, Oliver JH Jr (2011) Borrelia carolinensis sp. nov., a novel species of the Borrelia burgdorferi sensu lato complex isolated from rodents and a tick from the south-eastern USA. Int J Syst Evol Microbiol 61:381-383. https://doi.org/10.1099/ijs.0.021436-0

Rudenko N, Golovchenko M, Belfiore NM, Grubhoffer L, Oliver JH Jr (2014) Divergence of Borrelia burgdorferi sensu lato spirochetes could be driven by the host: diversity of Borrelia strains isolated from ticks feeding on a single bird. Parasites Vectors 7:4. https://doi.org/10.1186/1756-3305-7-4

Rupprecht TA, Manz KM, Fingerle V, Lechner C, Klein M et al (2018) Diagnostic value of cerebrospinal fluid CXCL13 for acute Lyme neuroborreliosis. A systematic review and metaanalysis. Clin Microbiol Infect 24:1234-1240. https://doi.org/ 10.1016/j.cmi.2018.04.007

Samuels DS, Lybecker MC, Yang XF, Ouyang Z, Bourret TJ et al (2021) Gene regulation and transcriptomics. Curr Issues Mol Biol 42:223-266. https://doi.org/10.21775/cimb.042.223

Schotthoefer AM, Frost HM (2015) Ecology and epidemiology of Lyme borreliosis. Clin Lab Med 35:723-743. https://doi.org/ 10.1016/j.cll.2015.08.003

Schwartz AM, Hickley AF, Mead PS, Hook SA, Kugeler KJ (2017) Surveillance for Lyme disease - United States, 2008-2015. MMWR Surveill Summ 66:1-12. https://doi.org/10.15585/ mmwr.ss6622a1

Schwartz I, Margos G, Casjens SR, Qiu W-G, Eggers CH (2021) Multipartite genome of Lyme disease Borrelia: structure, variation and prophages. Curr Issues Mol Biol 42:409-454. https:// doi.org/10.21775/cimb.042.409

Semenza JC, Menne B (2009) Climate change and infectious diseases in Europe. Lancet Infect Dis 9:365-375. https://doi.org/10.1016/ S1473-3099(09)70104-5

Semenza JC, Suk JE (2018) Vector-borne diseases and climate change: a European perspective. FEMS Microbiol Lett 365: fnx244 https://doi.org/10.1093/femsle/fnx244

Sharareh N, Sabounchi NS, Roome A, Spathis R, Garruto RM (2017) Model-based risk assessment and public health analysis to prevent Lyme disease. R Soc Open Sci 4:170841. https://doi.org/ $10.1098 /$ rsos. 170841

Skare JT, Garcia BL (2020) Complement evasion by Lyme disease spirochetes. Trends Microbiol 28:889-899. https://doi.org/10. 1016/j.tim.2020.05.004

Smith R, Takkinen J (2006) Lyme borreliosis - Europe-wide coordinated surveillance and action needed? Euro Surveill 11:E060622.1 https://doi.org/10.2807/esw.11.25.02977-en

Stanek G, Strle F, Gray J, Wormser GP (2002) History and characteristics of Lyme borreliosis. In: Gray JS, Kahl O, Lane RS, Stanek $\mathrm{G}$ (eds) Lyme borreliosis: biology, epidemiology and control. CABI Publishing, Oxon, UK, pp 1-28

Stanek G, Fingerle V, Hunfeld K-P, Jaulhac B, Kaiser R et al (2011) Lyme borreliosis: clinical case definitions for diagnosis and management in Europe. Clin Microbiol Infect 17:69-79. https://doi. org/10.1111/j.1469-0691.2010.03175.x

Steere AC, Malawista SE, Snydman DR, Shope RE, Andiman WA et al (1977) Lyme arthritis: an epidemic of oligoarticular arthritis in 
children and adults in three Connecticut communities. Arthritis Rheum 20:7-17. https://doi.org/10.1002/art.17802000102

Steere AC (2006) Lyme borreliosis in 2005, 30 years after initial observations in Lyme Connecticut. Wien Klin Wochenschr 118:625633. https://doi.org/10.1007/s00508-006-0687-x

Steere AC, Strle F, Wormeser GP, Hu LT, Branda JA et al (2016) Lyme borreliosis. Nat Rev Dis Primers 15:16090. https://doi.org/10. 1038/nrdp. 2016.90

Stevenson B, Schwan TG, Rosa PA (1995) Temperature-related differential expression of antigens in the Lyme disease spirochete, Borrelia burgdorferi. Infect Immun 63:4535-4539. https://doi. org/10.1128/IAI.63.11.4535-4539.1995

Stevenson B, El-Hage N, Hines MA, Miller JC, Babb K (2002) Differential binding of host complement inhibitor factor $\mathrm{H}$ by Borrelia burgdorferi Erp surface proteins: a possible mechanism underlying the expansive host range of Lyme disease spirochetes. Infect Immun 70:491-497. https://doi.org/10.1128/iai.70.2.491497.2002

Stone BL, Tourand Y, Brissette CA (2017) Brave new worlds: the expanding universe of Lyme disease. Vector Borne Zoonotic Dis 17:619-629. https://doi.org/10.1089/vbz.2017.2127

Strle F, Stanek G (2009) Clinical manifestations and diagnosis of Lyme borreliosis.s Curr Probl Dermatol 37:51-110 https://doi.org/10. $1159 / 000213070$

Strnad M, Hönig V, Ružek D, Grubhoffer L, Rego ROM (2017) Europe-wide meta-analysis of Borrelia burgdorferi sensu lato prevalence in questing Ixodes ricinus ticks. Appl Environ Microbiol 83:e00609-17. https://doi.org/10.1128/AEM.00609-17

Stupica D, Lusa L, Cerar T, Ružić-Sabljić E (2011) Comparison of post-Lyme borreliosis symptoms in erythema migrans patients with positive and negative Borrelia burgdorferi sensu lato skin culture. Vector Borne Zoonotic Dis 11:883-889. https://doi.org/ 10.1089/vbz.2010.0018

Sürth V, Lopes de Carvalho I, Núncio MS, Norte AC, Kraiczy P (2021) Bactericidal activity of avian complement: a contribution to understand avian-host tropism of Lyme borreliae. Parasit Vectors 14:451. https://doi.org/10.1186/s13071-021-04959-0

Swanson SJ, Neitzel D, Reed KD, Belongia EA (2006) Coinfections acquired from Ixodes ticks. Clin Micro Rev 19:708-727. https:// doi.org/10.1128/CMR.00011-06

Sykes RA, Makiello P (2017) An estimate of Lyme borreliosis incidence in Western Europe. J Public Health (Oxf) 39:74-81. https://doi.org/10.1093/pubmed/fdw017

The Lancet (2018) Introducing EU-wide surveillance of Lyme neuroborreliosis. 392:452https://doi.org/10.1016/S0140-6736(18) 31738-0

Tilly K, Bestor A, Rosa PA (2016) Functional equivalence of OspA and OspB but not OspC in tick colonization by Borrelia burgdorferi. Infect Immun 84:1565-1573. https://doi.org/10.1128/ IAI.00063-16

Tonetti N, Voordouw MJ, Durand J, Monnier S, Gern L (2015) Genetic variation in transmission success of the Lyme borreliosis pathogen Borrelia afzelii. Ticks Tick Borne Dis 6:334-343. https:// doi.org/10.1016/j.ttbdis.2015.02.007

Tsao JI (2009) Reviewing molecular adaptations of Lyme borreliosis spirochetes in the context of reproductive fitness in natural transmission cycles. Vet Res 40:36. https://doi.org/10.1051/ vetres/2009019

Tufts DM, Hart TM, Chen GF, Kolokotronis S-O, Diuk-Wasser MA et al (2019) Outer surface protein polymorphisms linked to host-spirochete association in Lyme borreliae. Mol Microbiol 111:868-882. https://doi.org/10.1111/mmi.14209

van Duijvendijk G, Coipan C, Wagemakers A, Fonville M, Ersöz J et al. (2016) Larvae of Ixodes ricinus transmit Borrelia afzelii and B. miyamotoi to vertebrate hosts. Parasit Vectors 9:97 https://doi. org/10.1186/s13071-016-1389-5 van den Wijngaard CC, Hofhuis A, Simões M, Rood E, van Pel W et al (2017) Surveillance perspectives on Lyme borreliosis across the European Union and European Economic area. Euro Surveill 22:30569. https://doi.org/10.2807/1560-7917.ES.2017.22.27. 30569

Vanthomme K, Bossuyt N, Boffin N, van Casteren (2012) Incidence and management of presumption of Lyme borreliosis in Belgium: recent data from the sentinel network of general practitioners. Eur J Clin Microbiol Infect Dis 31:2385-2390. https://doi.org/ 10.1007/s10096-012-1580-3

Verhey TB, Castellanos M, Chaconas G (2018) Antigenic variation in the Lyme spirochete: insights into recombinational switching with a suggested role for error-prone repair. Cell Rep 23:25952605. https://doi.org/10.1016/j.celrep.2018.04.117

Vollmer SA, Bormane A, Dinnis RE, Seelig F, Dobson ADM et al (2011) Host migration impacts on the phylogeography of Lyme Borreliosis spirochete species in Europe. Environ Microbiol 13:184-192. https://doi.org/10.1111/j.1462-2920.2010.02319

Vollmer SA, Feil EJ, Chu C-Y, Raper SL, Cao W-C et al (2013) Spatial spread and demographic expansion of Lyme borreliosis spirochaetes in Eurasia. Infect Genet Evol 14:147-155. https://doi. org/10.1016/j.meegid.2012.11.014

Voordouw MJ (2015) Co-feeding transmission in Lyme disease pathogens. Parasitology 142:290-302. https://doi.org/10.1017/S0031 182014001486

Walter M, Vogelgesang JR, Rubel F, Brugger K (2020) Tick-borne encephalitis virus and its European distribution in ticks and endothermic mammals. Microorganisms 8:1065. https://doi.org/10. 3390/microorganisms 8071065

Wang G, van Dam AP, Le Fleche A, Postic D, Peter O et al (1997) Genetic and phenotypic analysis of Borrelia valaisiana sp. nov. (Borrelia genomic groups VS116 and M19). Int J Syst Bacteriol 47:926-932. https://doi.org/10.1099/00207713-47-4-926

Wang G, Iyer R, Bittker S, Cooper D, Small J et al (2004) Variations in Barbour-Stoenner-Kelly culture medium modulate infectivity and pathogenicity of Borrelia burgdorferi clinical isolates. Infect Immun 72:6702-6706. https://doi.org/10.1128/IAI.72.11. 6702-6706.2004

Wilhelmsson P, Fryland L, Lindblom P, Sjöwall J, Ahlm C et al (2016) A prospective study on the incidence of Borrelia burgdorferi sensu lato infection after a tick bite in Sweden and on the Åland Islands, Finland (2008-2009). Ticks Tick Borne Dis 7:71-79. https://doi.org/10.1016/j.ttbdis.2015.08.009

Wilking H, Stark K (2014) Trends in surveillance data on human Lyme borreliosis from six federal states in eastern Germany, 20092012. Ticks Tick Borne Dis 5:219-224. https://doi.org/10.1016/j. ttbdis.2013.10.010

Wolcott KA, Margos G, Fingerle V, Becker NS (2021) Host association of Borrelia burgdorferi sensu lato: a review. Ticks Tick Borne Dis 12:101766. https://doi.org/10.1016/j.ttbdis.2021.101766

World Health Organization, WHO (2020) Vector-borne diseases. Available online: https://www.who.int/news-room/fact-sheets/detail/ vector-borne-diseases. (accessed 07.05.2021)

Wormser GP, Strle F, Shapiro ED, Auwaerter PG (2021) Comparison of the clinical practice guidelines for Lyme disease from the Infectious Diseases Society of America: 2000, 2006, and 2020. Diagn Microbiol Infect Dis 101:115446. https://doi.org/ 10.1016/j.diagmicrobio.2021.115446

Woudenberg T, Böhm S, Böhmer M, Katz K, Willrich N et al. (2020) Dynamics of Borrelia burgdorferi-specific antibodies: seroconversation and seroreversion between two population-based, cross-sectional surveys among adults in Germany. Microorganisms 8:1859 https://doi.org/10.3390/microorganisms8121859

Younger DS (2016) Epidemiology of Lyme neuroborreliosis. Neurol Clin 34:875-886. https://doi.org/10.1016/j.ncl.2016.05.005 
Zeman P (1997) Objective assessment of risk maps of tick-borne encephalitis and Lyme borreliosis based on spatial patterns of located cases. Int J Epidemiol 26:1121-1129. https://doi.org/10. 1093/ije/26.5.1121

Zhang JR, Hardham JM, Barbour AG, Norris SJ (1997) Antigenic variation in Lyme disease borreliae by promiscuous recombination of VMP-like sequence cassettes. Cell 89:275-285. https://doi. org/10.1016/s0092-8674(00)80206-8

Zhang JR, Norris SJ (1998) Kinetics and in vivo induction of genetic variation of vlsE in Borrelia burgdorferi. Infect Immun 66:36893697. https://doi.org/10.1128/IAI.66.8.3689-3697.1998
Zintl A, Zaid T, McKiernan F, Naranjo-Lucena A, Gray J et al (2020) Update on the presence of Ixodes ricinus at the western limit of its range and the prevalence of Borrelia burgdorferi sensu lato. Ticks Tick Borne Dis 11:101518. https://doi.org/10.1016/j.ttbdis. 2020.101518

Publisher's note Springer Nature remains neutral with regard to jurisdictional claims in published maps and institutional affiliations. 